\title{
LACUSTRINE, FLUVIAL AND SLOPE DEPOSITS IN THE WETLAND SHORE AREA IN SERTEYA, WESTERN RUSSIA
}

\author{
PIOTR KITTEL ${ }^{1}$, ANDREY MAZURKEVICH ${ }^{2}$, ALEXANDER ALEXANDROVSKIY ${ }^{3}$, \\ EKATERINA DOLBUNOVA ${ }^{2}$, MATEUSZ KRUPSKI ${ }^{4,9}$, JACEK SZMANDDA ${ }^{5}$, \\ RENATA STACHOWICZ-RYBKA ${ }^{6}$, KATARZYNA CYWA ${ }^{6}$, \\ AGNIESZKA MROCZKOWSKA ${ }^{1,7}$, DANIEL OKUPNY ${ }^{8}$
}

\begin{abstract}
The article presents the results of a study on sediment deposition processes in the palaeolake shore zone, at the multilayered Serteya II archaeological site in Western Russia. In recent years, geomorphological, palaeopedological and palaeoecological research was undertaken in strict cooperation with archaeological fieldwork. The Serteya II site occupies a substantial area of a kame terrace and biogenic plain within a palaeolake basin. From an archaeological point of view, the site is represented by few Mesolithic artefacts, but mostly by remnants of hunter-gatherer-fisher communities attributed in the Russian scientific tradition to the Neolithic period and dated from $6300 \mathrm{BC}$ to $2000 \mathrm{BC}$. Later, the area was used by people in the Bronze Age, Early Iron Age and Early Middle Ages. The integration of archaeological and multidisciplinary palaeoenvironmental research allowed the natural and human induced deposition of mineral-organic and minerogenic sediments to be reconstructed, as well as the development of structures in the lake shore zone. The changes from lacustrine to fluvial system were documented and the human impact is recorded mostly in the acceleration of slope processes.
\end{abstract}

Key words: sedimentology, micromorphology, micro- and macrofossils, geochemistry, palaeolake shore zone, archaeological layers

\section{Introduction}

The western part of the multi-layered Serteya II archaeological complex (Western Russia) is situated in a palaeolake shore area. It is characterised by a complex cultural stratigraphy due to its diversified geomorphological setting and different periods of inhabitation. The geomorphological condition of the Serteya II site was recently described by Kittel et al. (2018), and the latest archaeological discoveries have recently been presented by Mazurkevich et al. (2017) and Kittel et al. (2020).

The diversified geomorphological situation results from the studied site's location in a recently glaciated area. The terrain relief has been

\footnotetext{
${ }^{1}$ University of Lodz, Faculty of Geographical Sciences, Department of Geology and Geomorphology, ul. Narutowicza 88, 90-139 Łódź, Poland; e-mail: piotr.kittel@geo.uni.lodz.pl, ORCID: 0000-0001-6987-7968

${ }^{2}$ The State Hermitage Museum, Department of Archaeology of Eastern Europe and Siberia, Dvortsovaya Naberezhnaya 34, 190000 Saint Petersburg, Russia; e-mail: a-mazurkevich@mail.ru, ORCID: 0000-0002-4947-0498; katjer@mail.ru, ORCID: 0000-0003-1843-9620

${ }^{3}$ Russian Academy of Sciences, Institute of Geography, Department of Soil Geography and Evolution, Staromonetniy lane. 29, 119017 Moscow, Russia, Russia; e-mail: alexandrovskiy@mail.ru

${ }^{4}$ Archeolodzy.org Foundation, ul. Bolesława Prusa 81/3i, 50-316 Wrocław, Poland; e-mail: mateusz@archeolodzy.org, ORCID: 0000-0001-7992-967X

${ }^{5}$ Pedagogical University of Cracow, Institute of Geography, ul. Podchorążych 2, 30-084 Krakow, Poland; e-mail: jacek.szmanda@up.krakow.com, ORCID: 0000-0002-4058-8334

${ }^{6}$ W. Szafer Institute of Botany, Polish Academy of Sciences, ul. Lubicz 46, 31-512 Kraków, Poland; e-mail: k.cywa@botany.pl, r.stachowicz@botany.pl

7 Polish Academy of Sciences, Institute of Geography and Spatial Organization, ul. Twarda 51/55, 00-818 Warsaw, Poland; e-mail: A_Mroczkowska@outlook.com, ORCID: 0000-0002-3534-7843

${ }^{8}$ University of Szczecin, Institute of Marine and Environmental Sciences, ul. Mickiewicza 16, 70-383 Szczecin, Poland; e-mail: daniel.okupny@usz.edu.pl

9 Wrocław University of Environmental and Life Sciences, Institute of Soil Science and Environmental Protection, ul. Grunwaldzka 53, 50-357 Wrocław, Poland
} 
formed since the Late Weichselian (Late Valdai) and the site lies within a subglacial channel that was earlier occupied by a few lake basins and later by the Serteyka River Valley. The site is located within a valley, at the point where the valley crosses the border between areas of moraine and glaciofluvial sediments. Soil-forming rocks are heterogeneous, often layered, from sand to loams. The latter are found on terraces, and sands predominate in the valley floor. In general, sandy podzols predominate on the studied territory, while in the area of Serteya II $\alpha$ there are podzols on sands, in some places underlain by moraine diamicton.

Archaeological relicts, features and layers are found on a kame terrace, which is formed by clastic sediments (at part of the site called Serteya II layer $a$ ), as well as within lacustrine organic deposits of the palaeolake basin (Serteya II-2) (Fig. 1).
The surface of the kame occupied by the Serteya II layer $\alpha$ is slightly inclined east-north-eastwards and formed by glaciofluvial sands with admixtures of gravels and limnoglacial fine sands and silts. Numerous Neolithic artefacts and features were discovered at the Serteya II-2 site in: a brown coarse-detritus, a brown-olive coarse-detritus gyttja, and underlying sands with organic mud and clay admixture (see also Mazurkevich et al. 2020). The upper part of the muddy brown gyttja layer may be synchronous with the time when communities of the Textile Ceramics Culture dwelled at the higher part of the site, which is represented by Serteya II layer $\alpha$ and belongs to the Late Bronze Age of the first half-middle of the $2^{\text {nd }}$ millennium $\mathrm{BC}$, based on the dates obtained for similar complexes in other regions. These cultural layers are covered with sandy and silty organic mud deposits.
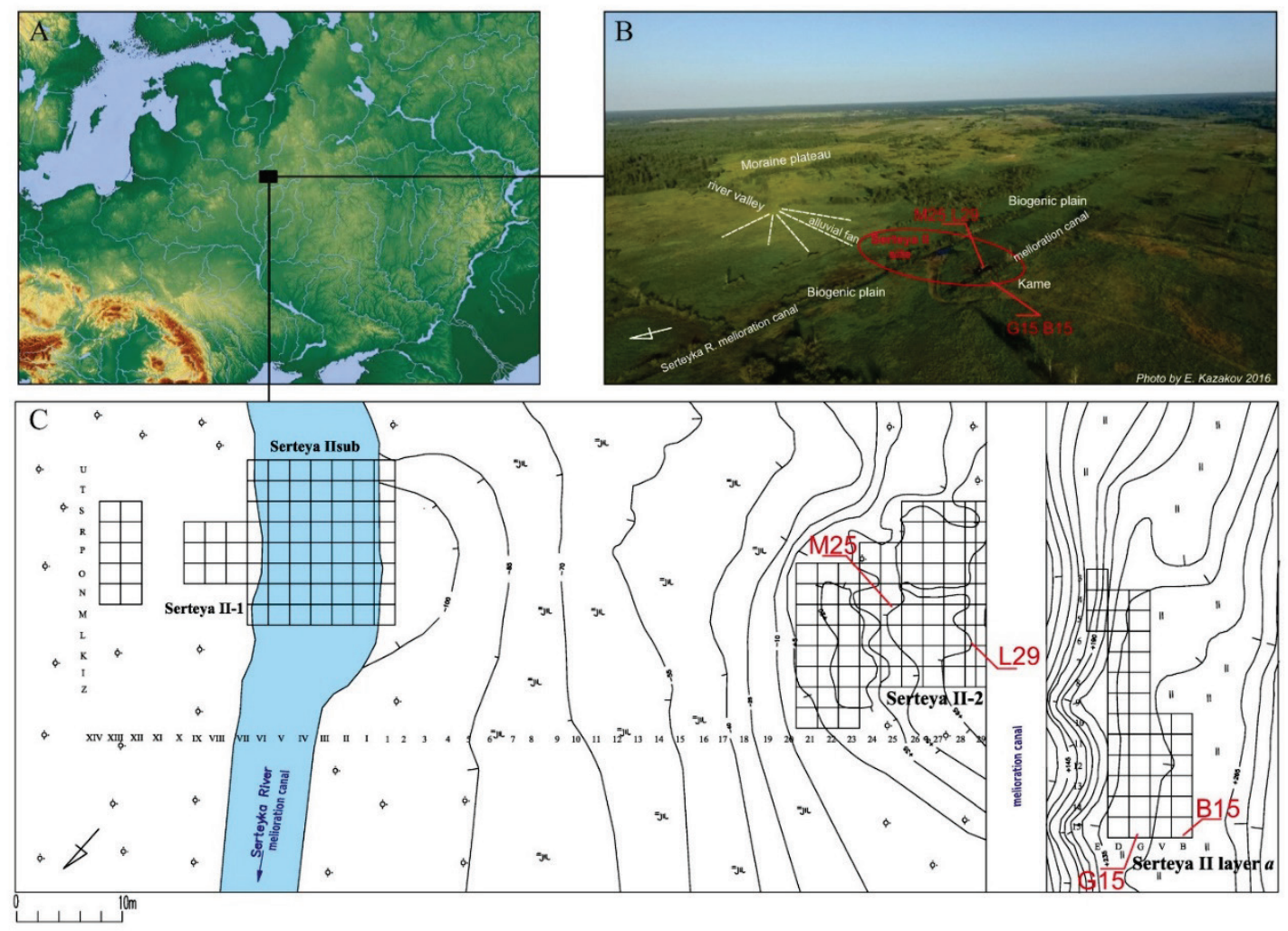

Fig. 1. Research area: Serteya II site plan indicating location of L29, M25, G15 and B15 cores

A. On the physical map of Europe (based on DEM)

B. On an aerial photo of the Serteya II site (photo by E. Kazakov 2016)

C. On the Serteya II site archaeological excavation plan

The accumulation of lacustrine deposits was replaced in the studied area by fluvial overbank deposition after $1650 \mathrm{BC}$ (after 3371 $\pm 21 \mathrm{BP}$ ) (Kittel et al. 2020). It may have occurred even later, as indicated by the discovery of a cow mandible in squares O26-O27 at the Serteya II-2 site (Fig. 1) at the border of muddy brown gyttja and a silty organic mud layer. This bone was dated to $1685 \pm 30$ 
BP (Poz-108410), i.e. 335-400 AD. Moreover, plant macrofossils from the overbank deposits obtained a date of 561 \pm 26 BP (MKL-A3888), i.e. 1324-1414 AD (Kittel et al. 2018, 2020). This demonstrates that the palaeolake water level possibly decreased in the studied area between $1500 \mathrm{BC}$ and $300 \mathrm{AD}$ and fluvial overbank deposition started before $1300 \mathrm{AD}$.

Our study is focused on Late Holocene changes in deposition processes in the palaeolake shore zone - from a lacustrine system to a fluvial system and with slope processes playing a role. These transitions were influenced by palaeoenvironmental conditions and the episodic impact of small human groups. The palaeoenvironmental conditions were reconstructed based on sedimentological, palaeopedological and palaeoecological traits of deposits of the palaeolake shore zone.

\section{Material and study methods}

The western shore zone part of the Serteya II site has been excavated since 2015 using wetland archaeological methods. The surficial geology of the site surroundings was recognised by detailed mapping with the use of hand augering. A more detailed study was undertaken in archaeological trenches. After a full excavation of the archaeological outcrop, a core of deposits was collected in square L29 for detailed multi-proxy analyses (Fig. 1). The L29 core was taken as a monolith in a metal box with dimensions of $50 \times 10 \times 10 \mathrm{~cm}$ (Fig. 2) and it covers the deposits between 65 and $115 \mathrm{~cm}$ below ground level (b.g.l.). This sampling method preserves the undisturbed structure of sediments. Sub-samples of the L29 core deposits were taken in 1-cm slices at 2-cm intervals for geochemical, sedimentological, palaeozoological (subfossil Cladocera and Chironomidae) and plant macrofossil analyses. Thin sections for micromorphological analysis were manufactured from the remainder of deposits protected in the metal box.

For the L29 core, chemical composition was determined for 21 samples after drying at $105^{\circ} \mathrm{C}$ and homogenisation in an agate mortar. The geochemical analysis included identification of: organic matter (LOI) in a muffle furnace at $550{ }^{\circ} \mathrm{C}$, calcium carbonate $-\mathrm{CaCO}_{3}$ (volumetric method by means of Scheibler's apparatus) (methods after: Bengtsson, Enell 1986). The ash samples were dissolved (with $\mathrm{HCl}, \mathrm{HNO}_{3}$ and $\mathrm{H}_{2} \mathrm{O}_{2}$ ) in Teflon bombs using a microwave mineraliser for 21 samples. The obtained solution was analysed for concentrations of selected elements, using atomic absorption spectrometry (SOLAAR 969 Unicam). The proportions of these compounds (such as: $\mathrm{Fe} / \mathrm{Mn}, \mathrm{Cu} / \mathrm{Zn}, \mathrm{Ca} / \mathrm{Fe}, \mathrm{Na} / \mathrm{K}, \mathrm{Ca} / \mathrm{Mg}$ and $\mathrm{Na}+\mathrm{K}+$ $+\mathrm{Mg} / \mathrm{Ca}$ ) were used to classify deposits and to reconstruct environmental change in the sedimentary basin and in its catchment (Pawłowski et al. 2016). The key assumption of these interpretations is that lithophilic and biogenic elements derive from different sources and that they accumulate in deposits in different physico-chemical conditions. The grain-size composition of the ash samples remaining after Loss-On-Ignition analysis, was determined using a laser particle size analyser Mastersizer 3000 with a Hydro MU dispersion unit (Malvern).

The origins and conditions of sediment deposition were interpreted on the basis of Mycielska-Dowgiałło and Ludwikowska-Kędzia (2011), using the Folk and Ward (1957) indices based on the distribution of samples on the relationship diagram of mean grain size $\left(\mathrm{M}_{\mathrm{Z}}\right)$ and sorting $\left(\sigma_{1}\right)$. Moreover, the momentary indices of grain-size composition of the samples were calculated, and the conditions of sediment deposition were interpreted by analysing the distribution of the samples on the mean grain size $\left(\mathrm{M}_{1}\right)$ versus standard deviation $\left(\mathrm{M}_{2}\right)$ diagram, referring to the views of Sly et al. (1983). Depositional velocities of water flow were calculated based on the values of the mean grainsize diameter, according to Koster's (1978) formula. Shear velocities of water flow were estimated based on the first percentile and Sundborg (1967) diagram.

Three undisturbed soil blocks were sub-sampled from the L29 monolith sample for soil micromorphology analysis, at depth ranges 80-90, 90-100 and 100-110 (cm b.g.l.), capturing horizons described as: 1 - organic mud (called OM, 110-109 cm), 2 - sand with organic mud (SOM, 109-100/96 cm), and 3 - muddy sand with organic matter and silty organic mud at the top (OSOM, at 100/96-80 cm) (Fig. 2). The samples were airdried, impregnated with resin, cut and polished to a thickness of $c a 30 \mu \mathrm{m}$ in the Laboratory of Mineralogy and Petrology, Ghent University. The procedure of thin section production did not include acetone replacement. Air drying of samples causes shrinkage of organic matter, which leads to an artificial increase in porosity. Thus, the estimates of porosity in thin sections have to be taken with caution. The thin sections were first scanned and analysed macroscopically to allow correlation with field observations and preliminary identification of microstructure. Microscopic observations were conducted using a Zeiss Axio Lab A1 in plane polarised light (PPL), cross-polarised light (XPL) and 
oblique incident light (OIL), in magnifications ranging from $25 \times$ to $200 \times$ (Courty et al. 1989; Goldberg, Macphail 2006; Nicosia, Stoops 2017). Standard terminology of Bullock et al. (1985) and
Stoops (2003) was used for descriptions of micromorphological features, whereas phytolith distribution patterns were recognised following Vrydaghs et al. (2016).

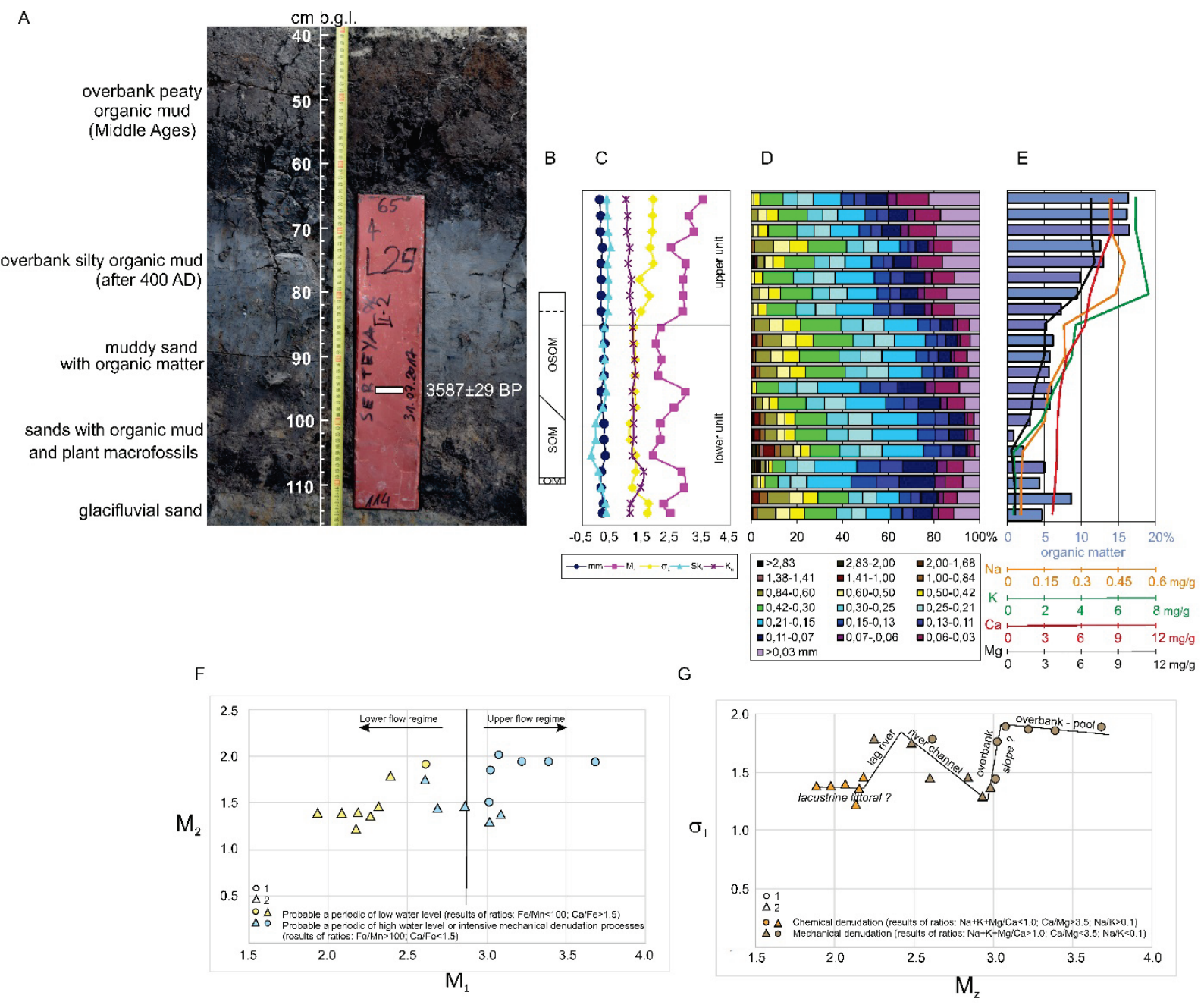

Fig. 2. Lithology, sedimentological and geochemical traits of STII L29 core deposits

A. Lithologic profile

B. Micromorphological units

C. Folk and Ward coefficients

$\mathrm{mm}-$ mean grain size [mm], $\mathrm{M}_{\mathrm{z}}$ - mean grain size [phi], $\sigma_{1}$ - sorting index, $\mathrm{Sk}_{1}-$ skewness, $\mathrm{K}_{\mathrm{g}}-$ kurtosis

D. Grain-size distribution

E. Content of organic matter and $\mathrm{Na}, \mathrm{K}, \mathrm{Ca}, \mathrm{Mg}$ elements

F. Lithodynamic interpretation of sediments after Sly et al. (1983) (analysis by J. Szmańda) against water levels reconstructed based on geochemical indicators: $\mathrm{Fe} / \mathrm{Mn}, \mathrm{Cu} / \mathrm{Zn}$ and $\mathrm{Ca} / \mathrm{Fe}$ (analysis by D. Okupny)

1 - sediments of upper unit $\mathrm{U} 1 ; 2$ - sediments of lower unit U2

G. Lithogenetic interpretation of sediments after Mycielska-Dowgiałło, Ludwikowska-Kędzia (2011) modified (analysis by J. Szmańda) against type of denudation processes reconstructed based on geochemical indicators: $\mathrm{Na} / \mathrm{K}$ and $\mathrm{Ca} / \mathrm{Mg}$ (analysis by D. Okupny)

1 - sediments of upper unit $\mathrm{U} 1 ; 2$ - sediments of lower unit U2 
Plant macrofossil analysis was carried out for 21 samples $\left(15-20 \mathrm{~cm}^{3}\right.$ each) from the L29 profile. The samples were boiled with $\mathrm{KOH}$ to reduce the amount of sediment and remove humic matter, and then the material was examined with a stereo microscope. The conservation of the plant remains was done with a standard mixture of alcohol, water and glycerin in proportion 1:1:1, with the addition of thymol. Then, the fragments of the plants were dried with $50 \%$ ethyl alcohol and identified with the use of plant keys, atlases (e.g. Berggren 1969; Cappers et al. 2006; Velichkevich, Zastawniak 2006, 2008), other scientific descriptions and publications, a reference collection of contemporary seeds, fruits and wood, and a collection of fossil floras in the Palaeobotanical Museum of the W. Szafer Institute of Botany, Polish Academy of Sciences in Kraków. Qualitative and quantitative results were presented in diagrams, and drawn using the POLPAL software (Nalepka, Walanus 2003).

The samples for subfossil Cladocera analysis were processed according to Frey (1986). Microscopic identification $(200 \times$ and $400 \times$ magnification) was based on a key by Szeroczyńska and Sarmaja-Korjonen (2007). Qualitative analysis was based on Bjerring et al. (2009). The samples for subfossil Chironomidae analysis were processed with standard methods described by Brooks et al. (2007) using a 90- $\mu \mathrm{m}$ sieve. Head capsules were separated from the sediment under binoculars $(4 \times 10$ magnification) and identified under a microscope (mainly 10 $\times 40$ magnification). The identification and ecological analysis follow mostly Brooks et al. (2007) and Andersen et al. (2013). The weight of the samples ranged from 15.48 to $32.48 \mathrm{~g}$. Zonation of both Cladocera and Chironomidae analyses' results was done using CONISS software (Grimm 1987) and the stratigraphic diagram was prepared with Tilia software (Grimm 2016).

In this study, three more lithological cores were also taken into consideration. The first one, called STII M25, was located $c a 8 \mathrm{~m}$ to the east of L29 (Figs 1, 3) and has been described in detail by Kittel et al. (2020). Two more profiles were situated at the Serteya II layer $\alpha$ site, on the kame surface, $c a 25 \mathrm{~m}$ to the west of the L29 core. They were collected from the wall of an archaeological trench in square $\mathrm{G} / 15$ and in square $\mathrm{B} / 15$ (Fig. 1). A number of geoarchaeological soil methods were used to characterise the natural and anthropogenic formation processes of deposits, cultural layers and soils at the Serteya II layer $\alpha$ site. The $\mathrm{G} / 15$ profile was sampled for palaeopedological, textural, geochemical and charcoal analyses. For the $\mathrm{B} / 15$ profile, only palaeopedological and geochemical analyses were conducted. Particle-size distribution using sieve analysis (Rühle 1973) was determined for seven sediment samples from the G/15 profile. The textural features, using Folk and Ward (1957) coefficients, the type of relationship between mean grain size $\left(\mathrm{M}_{\mathrm{Z}}\right)$ and sorting $\left(\sigma_{1}\right)$ after Mycielska-Dowgiałło and Ludwikowska-Kędzia (2011) and the C-M pattern after Passega and Byramjee (Passega 1964; Passega, Byramjee 1969) were evaluated for inferences about the origin and deposition conditions of sediments. The organic matter content was measured by routine methods: Loss-On-Ignition (LOI) for the G/15 profile and the Tyurin method (wet combustion, similar to the Walkley-Black method) for the $\mathrm{B} / 15$ profile. Soil $\mathrm{pH}$ was specified with a potentiometer in the water soil suspension and the total $\mathrm{P}_{2} \mathrm{O}_{5}$ content by the Ginzburg method (Ginzburg 1981; Bengtsson, Enell 1986).

Six samples of charcoal were subjected to anthracological analysis. The charcoal particles were selected manually from the $\mathrm{G} / 15$ profile, from the depths of 50-60, 60-65 and 65-70 cm b.g.1 and from the fill of a Neolithic pit. The samples contained from one to several charred wood fragments of length between 0.6 and $2.8 \mathrm{~cm}$. In total, the taxonomic attribution of 21 fragments of charcoal was determined. The charcoal fragments were analysed in reflected light, under a Nikon Eclipse ME600P metallurgical microscope. To verify the taxonomical determinations, a reference wood collection of the W. Szafer Institute of Botany, Polish Academy of Science was used, as well as atlases of wood anatomy (Schweingruber 1978; Benkova, Schweingruber 2004).

\section{Results}

\section{L29 core}

\section{Macroscopic description and chronology}

The bottommost sediments of the studied L29 depositional sequence are sands with organic mud and plant macrofossils (depth from 114 to $c a$ $100 \mathrm{~cm}$ b.g.l). Above, at a depth between $c a 100$ and $83 \mathrm{~cm}$ b.g.l. muddy sand with organic matter was identified, which passes gradually upward into silty organic mud (ca $83-c a 70 \mathrm{~cm}$ b.g.l.). The uppermost part of the profile is formed by peaty organic mud (Fig. 2). The bottommost sands with organic mud correspond to sediments of similar traits in the STII M25 core situated $c a 8 \mathrm{~m}$ to the 
east and chronologically correlated with the Early Holocene up to $c a 4300 \mathrm{BC}$ (Kittel et al. 2020). For the layer of muddy sand with organic matter, a ${ }^{14} \mathrm{C}$ date was obtained for macrofossils from a depth of $95 \mathrm{~cm}$ b.g.l. (i.e. Pinus sylvestris - 1 scale, Urtica dioica -2 fruits, Cristatella mucedo -7 statoblasts, charcoal - 3 fragments): $3587 \pm 29$ BP (MKLA4888), i.e. 1971-1896 cal. BC (prob. 68.2\%). The silty organic mud was deposited after $c a 400$ $\mathrm{AD}$, as demonstrated by the ${ }^{14} \mathrm{C}$ date of a cow's mandible in square $\mathrm{O} 27$ and plant macrofossils from the STII M25 core (Kittel et al. 2020).

\section{Geochemistry and sedimentology}

From the sedimentological point of view, the studied mineral deposits of the L29 core can be divided into two main units: (1) the lower (115$85 \mathrm{~cm}$ b.g.l.) and (2) the upper $(85-65 \mathrm{~cm})$ (Fig. 2C). The lower unit consists of sands and silt sands with a mean grain size of 1.94-3.02 phi $(0.26-0.12 \mathrm{~mm})$, average organic matter content below $5 \%$ and low concentration of $\mathrm{K}(0.3-1.8$ $\mathrm{mg} / \mathrm{g}), \mathrm{Na}(0.05-0.22 \mathrm{mg} / \mathrm{g}), \mathrm{Mg}(0.3-2.95 \mathrm{mg} / \mathrm{g})$ and $\mathrm{Ca}(3.5-6.2 \mathrm{mg} / \mathrm{g})$. The upper unit consists of silty sands with mean grain size $3.02-3.68$ phi $(0.13-0.08 \mathrm{~mm})$, average organic matter content of $12 \%, \mathrm{~K}$ of $7.16 \mathrm{mg} / \mathrm{g}$, Na of $0.43 \mathrm{mg} / \mathrm{g}$ and $\mathrm{Mg}$ of $6.55 \mathrm{mg} / \mathrm{g}$ (Fig. 2E). Both analysed units are poorly sorted and have a massive structure, but the structure of the deposits between $c a 100$ and 110/115 cm b.g.l. is deformed (Fig. 3).

In both units (i.e. sands and silty sands), the fraction of fine or medium sands with modes in the range from $1.37 \mathrm{phi}(0.39 \mathrm{~mm})$ to $2.37 \mathrm{phi}$ $(0.2 \mathrm{~mm})$ dominates (Fig. 2D). The content of medium sand fraction is at a maximum of $35 \%$ (at a depth of $85 \mathrm{~cm}$ ) and the fine sand fraction - 38\% (at a depth of 100-103 cm). In the silty sand, the accessory fraction is coarse silt -6 phi $(0.014 \mathrm{~mm})$, and its content reaches $8 \%$ (at a depth of $70 \mathrm{~cm}$ ). The particle-size distribution of deposits is positively skewed, which means that the modal fraction values are greater than the median.

The lower unit is underlain by glaciofluvial moderately sorted sands with gravel admixtures the mean grain size ranges from 2.23 to 2.73 phi $(0.21-0.15 \mathrm{~mm})$.

\section{Micromorphology}

Table 1 summarises the results of micromorphological observations. The development of microstructure is visible in the studied sequence: starting from a single grain type (mostly quartz grains) with a network of simple packing voids and relatively high porosity (OM: up to $50 \%$ ), characteristic for the OM and the SOM (109-100 $\mathrm{cm}$ b.g.l.); through dominant bridged and pellicular grain types with compound packing voids, few channels and planar voids and lower porosity (ca 30\%) in the SOM/OSOM and OSOM (100$90 \mathrm{~cm}$ ); to channel and platy microstructure types, which are exclusive in the least porous $(15-20 \%)$ uppermost part of the OSOM $(83-80 \mathrm{~cm})$, formed by silty organic mud (Figs $2 \mathrm{~B}, 4$ ). In terms of the related distribution of the coarse and fine mineral fraction (C:F limit at $2 \mu \mathrm{m}$ ), this corresponds with a shift from the monic (OM and SOM) to the porphyric type, where mineral grains are embedded in a "dusty" clay (clay with organic punctuations and detritus) matrix (OSOM: 83-80 cm). Gefuric/chitonic types are found in between (especially at $100-90 \mathrm{~cm}$ ). The b-fabric manifests itself as grano- and porostriated in the OSOM horizon. A ca 1-cm-thick "intercalation" of medium and coarse sand in the SOM (ca $105 \mathrm{~cm})$ and occasional "dusty" clay "crusts" capping mineral grains in the OSOM $(96-90 \mathrm{~cm})$ were identified; elsewhere, the well-to-moderately sorted mineral material is randomly oriented and distributed (no bedding or laminations).

The highest number of well preserved, brownish in colour, terrestrial plant remains (foliage twigs and leaves, seeds, other tissue fragments - bark?, sphagnum moss?), mostly horizontally aligned, were recorded in the OM (50$70 \%)$. They are frequent (15-30\%), including in the SOM (apart from "mixed" areas), but seem more fragmented (detritus). In the overlying SOM/OSOM and OSOM the amount of plant remains decreases (OSOM, depth $83-80 \mathrm{~cm}$ : $<5 \%$ ) and they become increasingly mineralised - carbonised, humified (rarely) or pseudomorphosised by $\mathrm{Fe} / \mathrm{Mn}$ replacement (Fe/Mn ratio exceeds 273, as shown by geochemical results). On the other hand, the uppermost part of the OSOM (83-80 $\mathrm{cm}$ ) has the highest percentage ( $\mathrm{ca} 5 \%$ ) of punctuations and amorphous forms (rare), which are absent or rare $(<5 \%$-single) in the OM and SOM, respectively. The fine organic matter (e.g. punctuations) is found embedded in the clay matrix. A similar pattern pertains to the phytolith assemblage, which is most abundant $(<5 \%,<5 \%$-single) in the topmost section of the sampled profile (OSOM, 90-80 cm), where also single diatoms and sponge spicules were discovered; siliceous particles occur within the (dusty) clay matrix. 


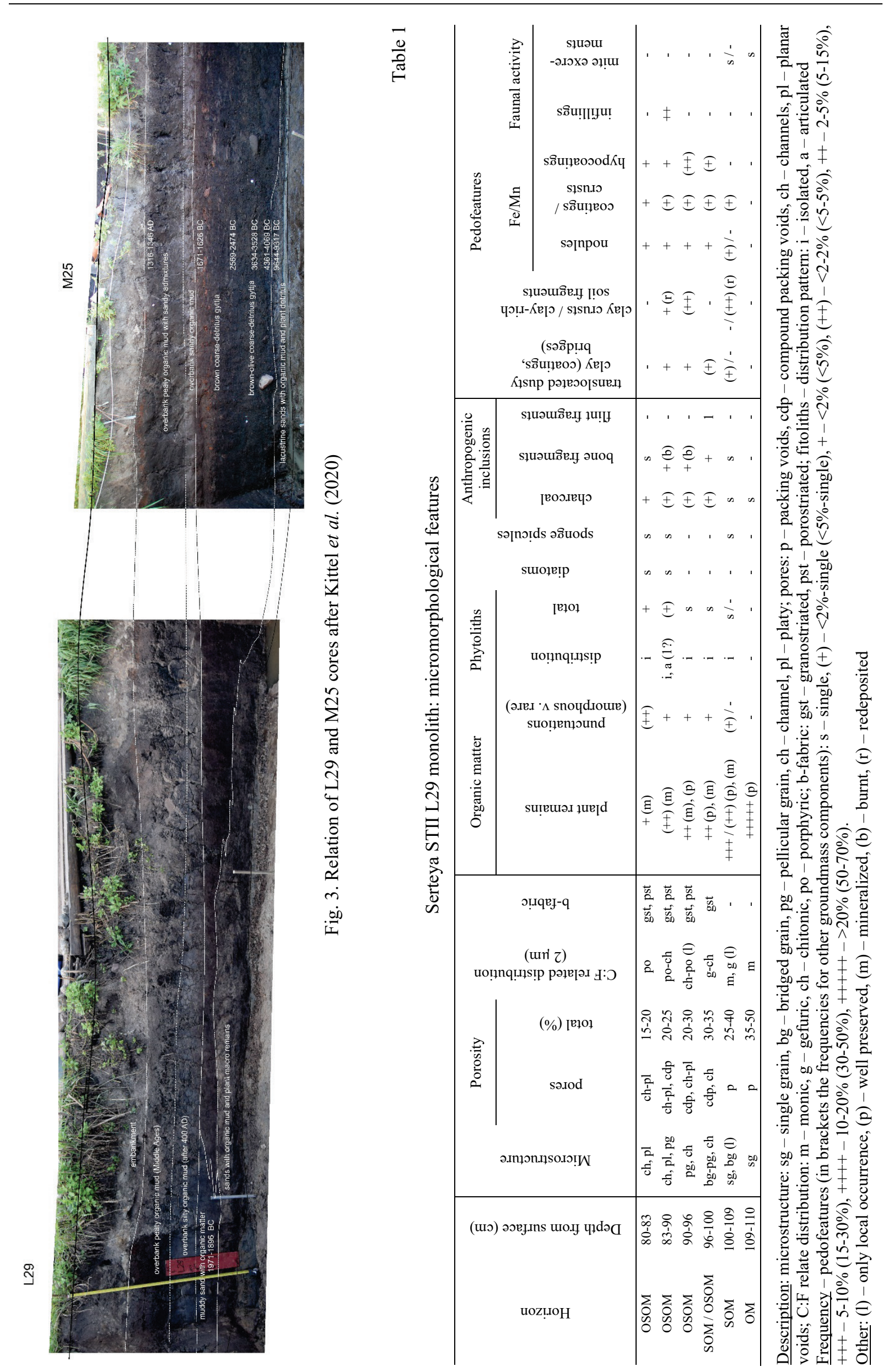



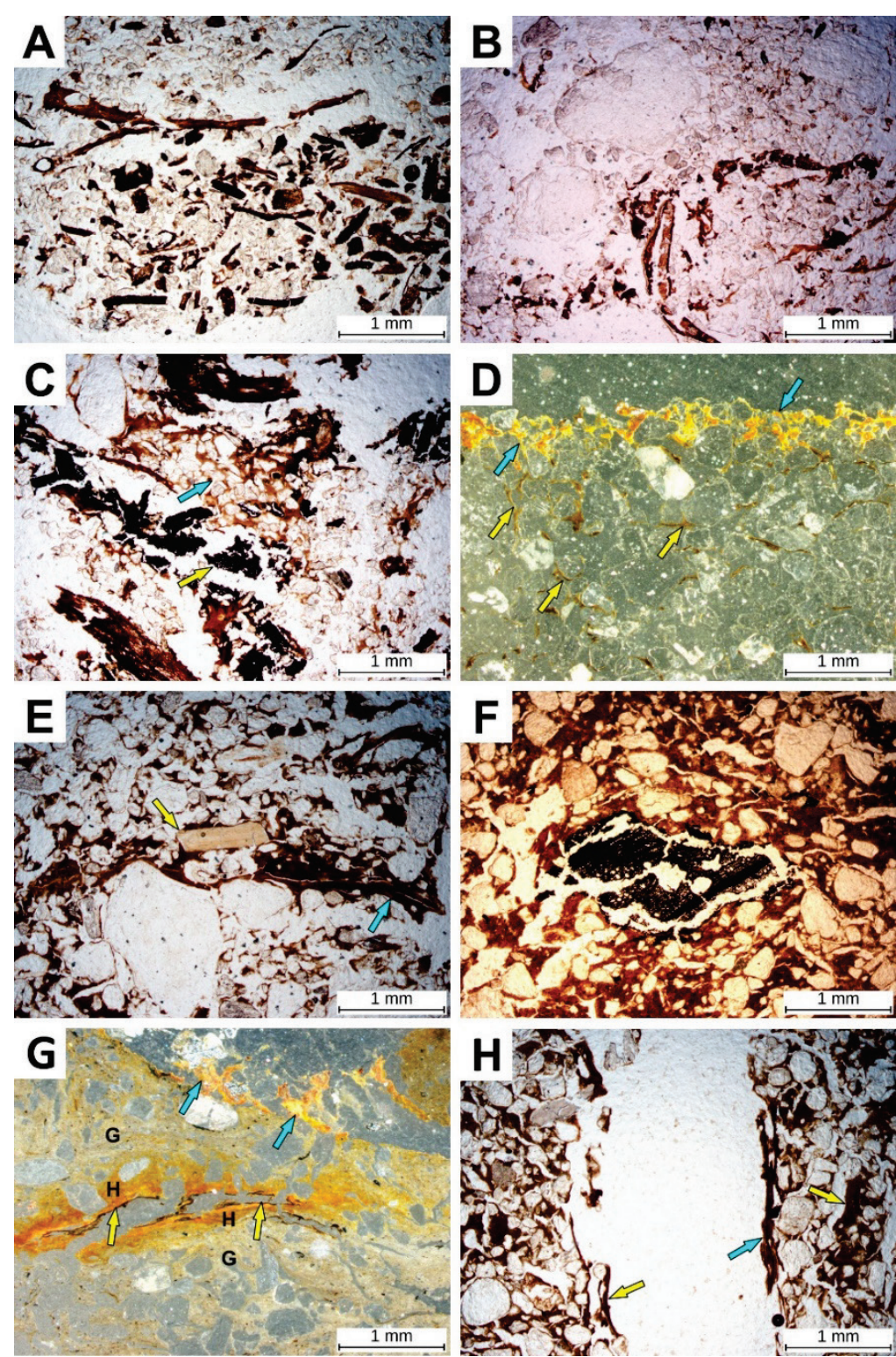

Fig. 4. Selected micromorphological features of STII L29 core deposits (analysis by M. Krupski)

A. Well-preserved plant remains and sand (OM, lower half of photo) and SOM (upper half). PPL

B. Boundary between undisturbed microfabric of SOM (right half of photo) and "mixed" zone. PPL

C. Redeposited (?) elements of "mixed" zone microfabric: charcoal (yellow arrow) and clay-rich soil fragment (blue arrow). PPL

D. Iron oxide precipitation around sand grains (blue arrows) in uppermost part of SOM. Clay coatings/bridges around and between sand grains (yellow arrows). OIL

E. Moderately sorted sand grains of the OSOM bridged and coated/capped by organic-rich clay with $\mathrm{Fe} / \mathrm{Mn}$ staining (blue arrow). Note horizontally aligned fragment of bone (yellow arrow). PPL

F. Charcoal (middle) and moderately sorted sand grains embedded in a matrix of clay containing organic particles (dusty clay), in uppermost studied part of OSOM. PPL

G. Redoximorphic features in uppermost part of OSOM: depletion (G) and precipitation of Fe/Mn: hypocoatings (H) and coatings (yellow arrows) along a pore, Fe-pseudomorphosised plant remains in a channel (blue arrows). OIL

H. Vertical soil fauna channel with dusty clay coatings (yellow arrows) and Fe/Mn-pseudomorphosised plant remains (blue arrow). PPL

type of light: PPL - plane polarised light, OIL - oblique incident light 
The muddy sand with organic matter (OSOM) seems to be relatively enriched in anthropogenic inclusions - charcoal, bone fragments $(<2 \mathrm{~mm}$ in size, some of them apparently burnt) and a single flint fragment (100-96 cm), while in the underlying SOM and OM only single charcoal and bone fragments were identified, mostly within the "mixed" zone of the SOM.

Clay translocation features (dusty clay coatings and bridges) are characteristic for the profile, being very rare in the uppermost part of the SOM (bridges, $<2 \%$-single) and best pronounced in the OSOM $(96-83 \mathrm{~cm})$. Clay crusts (dusty clay) most likely of a sedimentary nature - that cap mineral grains were found in situ in the OSOM - they also occur in redeposited, randomly oriented form (angular clay-rich soil fragments) in the "mixed" zone in the SOM or as channel infilling material in the OSOM (90-83 cm). Redoximorphic features are prominent in the sequence: they appear at the interface of the SOM and OSOM $(c a 100 \mathrm{~cm})$ and above, and take the form of nodules, hypocoatings along channel walls, and coatings. Concentrations of redox features (organic matter pseudomorphosis, coatings) locally also form horizontal "iron- pans"/"crusts" - the continuity of one of which seems to be cut in the SOM by the edge of the "mixed" zone. Soil fauna activity is evidenced by void infillings in the OSOM and mite excrements recognised on single plant remains in the $\mathrm{OM}$ and SOM.

\section{$\underline{\text { Plant macrofossils }}$}

Phase I (Se-1 L MAZ, 114-106 cm b.g.1.) (Fig. 5). In this phase, the remains of aquatic shallow standing water plants such as Nuphar lutea, Potamogeton pussilus or Potamogeton gramineus are present. The yellow water lily prefers eutrophic lakes, while the aforementioned Potamogeton species grow in cool waters with different trophic ranges from meso- to eutrophic. In this phase of the lake's existence, rush vegetation (probably of the type Magnocaricion with Carex pseudocyperus, Lycopus europaeus, Schoenoplectus lacustris and Mentha aquatica) also grew on its shores. Moist, nitrophilous and periodically flooded banks were occupied by the type of riparian forests of Alnus glutinosa and Urtica dioica. Meanwhile, spruce grew in drier places.

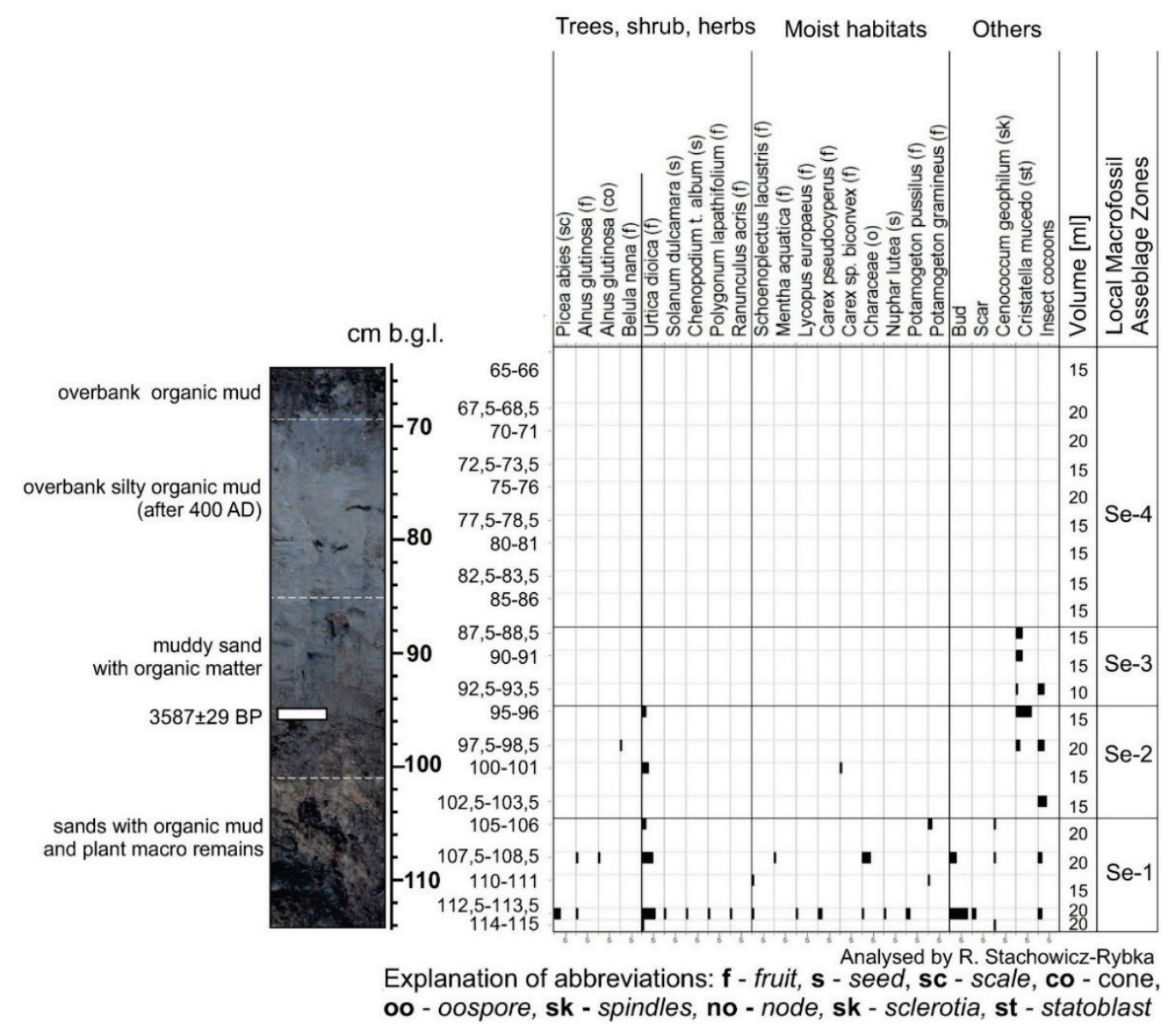

Fig. 5. Plant and other macrofossil diagram for STII L29 core deposits (analysis by R. Stachowicz-Rybka) 
Phase II (Se-2 L MAZ, 106-96 cm) at this level the share of plant remains decreased, and the water macrophytes in particular disappeared. Among the plant macrofossils representing the aquatic environment, there were only the bryozoans Cristatella mucedo, which now most often occur in cool and clear waters with a temperature of usually around $+16^{\circ} \mathrm{C}$ (Økland, Økland 2000). Carex sp. biconvex and Urtica dioica continued to grow in moist, hightrophy habitats. Moreover, Betula nana, a species characteristic of the cool, boreal climate, appeared. Nevertheless, at present it occurs in a relict form in NE Russia - in the Novgorod Oblast and the Tver Oblast, i.e. regions adjacent to the Smolensk Oblast. (https://www.discoverlife.org/mp/20q?search=Betula+nana\&guide). On the other hand, it is also possible that Betula nana nuts were redeposited from the Late Vistulian (Valdai) deposits.

Phase III (Se-3 L MAZ, 96-87.5 cm) contains very few plant remains, among which only Cristatella mucedo statoblasts were determined. This indicates that water conditions were still maintained. Insect remains are also present.
Phase IV (Se-4 L MAZ, 87.5-63 cm), the lack of plant macrofossils may suggest a quick flow of clastic material and processes of decomposition of organic remains.

\section{$\underline{\text { Palaeozoological fossils }}$}

\section{Cladocera}

Phase I (wet stage: 114-100 cm b.g.l.) (Fig. 6). This is the phase with the highest Cladocera abundance. Pelagic species such as Bosmina longispina and Bosmina coregoni occur in this phase. The sediment-associated taxa represent Monospilus dispar, eutrophic Alona guttata and Leydigia leydigia. Warm littoral species such as Graptoleberis testudinaria, Chydorus sp. and Kurzia lattisima occur as well. At a depth of $102.5 \mathrm{~cm}$ there appears Alona quadrangularis, which inhabits the littoral zone of stagnant waters. It is an open-water phase, with rapid shallowing at its final stage.

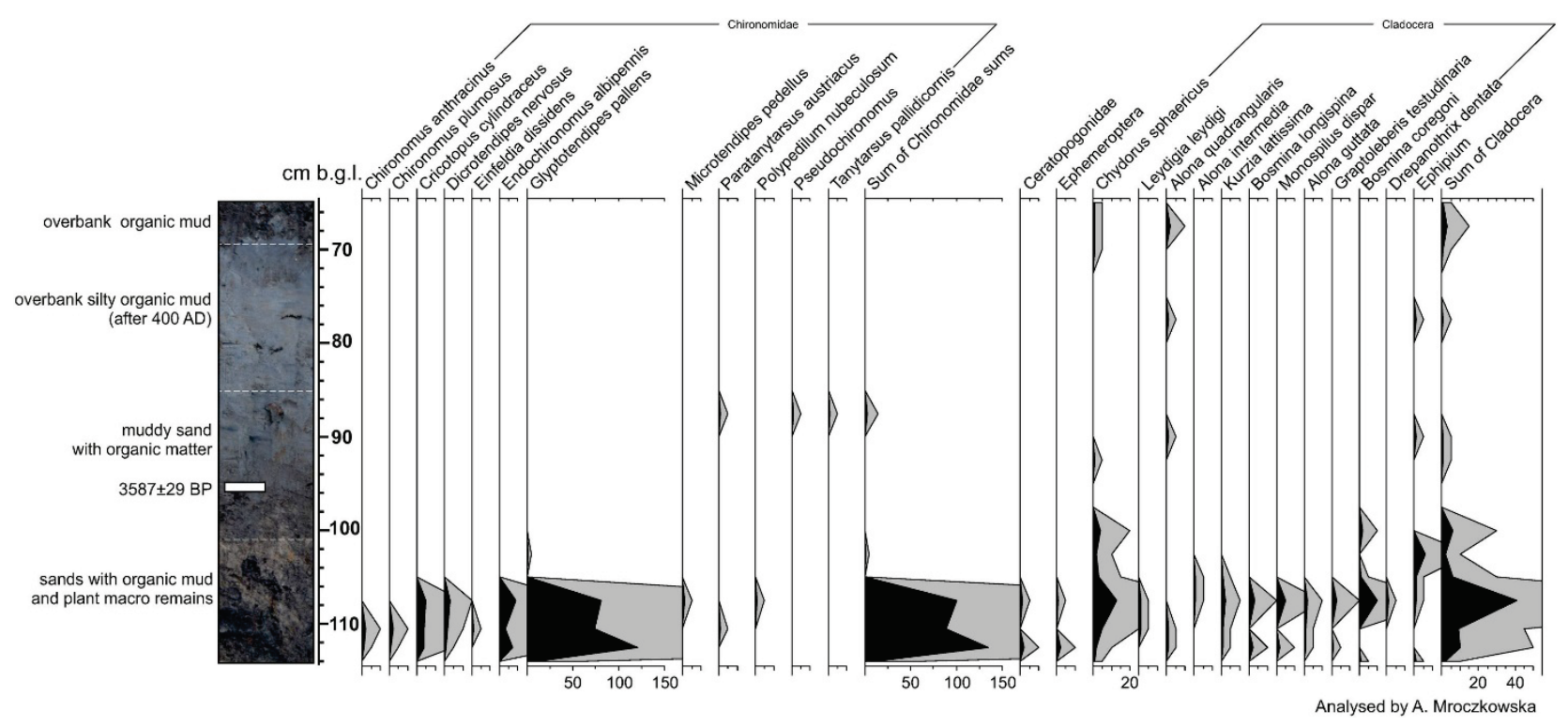

Fig. 6. Sum of subfossil Chironomidae and Cladocera remains for STII L29 core deposits (analysis by A. Mroczkowska)

Phase II (drought with episodic water level increase: $97.5-72.5 \mathrm{~cm}$ ). During this phase, only single Chydorus sp. and Alona quadrangularis appear. The first species is a ubiquistic taxon with a large tolerance range. The temporary lack of Cladocera points towards episodes with an increased inflow of sediment to the periodic water bodies, which demonstrates shallowing and terrestrialisation processes (Pawłowski et al. 2013).
Phase III (wetter condition: 72.5-65 cm). Alona quadrangularis and Chydorus sp. indicate the presence of an at least semi-permanent water body.

\section{Chironomidae}

Phase I (wet phase: 114-107.5 cm b.g.1.). In the first phase, the Glyptotendipes type pallens is abundant. This species is associated with decaying 
coarse organic matter at the lake littoral bottom and with macrophytes. Its larvae have a relatively high resistance to freezing. Endochironomus type albipennis and Dicrotendipes type nervosus are secondary taxa in the communities. They also inhabit the littoral of meso-eutrophic lakes and are sometimes reported from plant microhabitats. The other recorded taxon - Cricotopus type cylindraceus - is found in eutrophic lakes and mesosaprobic flowing waters. Ceratopogonidae are found in great numbers on aquatic plants occupying a wide range of ecological niches. Besides midges, Ephemeroptera larvae subfossils were discovered. Many mayflies are abundant in running waters (Brooks et al. 2007).

Phase II (dry phase: 107.5-65 cm). In this phase Chironomidae nearly completely disappear. The main factors that might cause the lack of Chironomidae communities are large inflows of sediments (river inflow, flooding or flushing, or slope wash processes), shallowing of the pond and/or the presence of cyanobacteria blooms (Nolte 1989; Jeppesen et al. 2001). At the core depth of $87.5 \mathrm{~cm}$ there are a few specimens of the Paratanytarsus type austriacus, Pseudochironomus prasinatus and Tanytarsus type pallidicornis. These morphospecies occur in the littoral zone of lakes, often on sandy bottoms (Pinder 1983), as well as in colder climatic conditions (like Paratanytarsus type austriacus, which is associated with macrophytes) (Buskens 1987; Brooks et al. 2007). T. pallidicornis type and $P$. austriacus type have been recorded in European stagnant and flowing waters, whereas Pseudochironomus type inhabits only stagnant waters. The $P$. austriacus reveal one spring generation in cold-temperate climate, whereas in warm-temperate regions of Eastern Europe it can reveal also a second, summer generation. T. pallidicornis type is a multivoltine species. Pseudochironomus type has one long generation that emerges in late summer. In Western Europe, Pseudochironomus prasinatus overwinter in second, third and fourth instar. The above indicates that all three species' third and fourth instar larvae could be found in winter and spring (until April) in the Serteyka River-lake backwaters (Giłka 1999, 2011; Moller Pillot 2009). The third and fourth instars larvae head capsules mostly accumulate in sediments (Brooks et al. 2007), and those instars were collected from the $87.5 \mathrm{~cm}$ layer in the L29 II zone.

\section{Serteya II layer $\alpha$ profiles}

Soils of the settlement Serteya II layer $\alpha$ partly represent the nature of Mid-Holocene pedogenesis (Aleksandrovsky, Aleksandrovskaya 2005). The studied profiles were located in the lower part of a gentle slope of the present day Serteyka River, in squares G/15 and B/15 (Fig. 1). The cultural horizons of the Early Middle Ages, Bronze Age and Neolithic were recorded in the G/15 profile, buried by slope deposits of the most recent centuries and a modern dump. The investigated profile was located between two Neolithic pits filled with dark, almost black, soil material. Here, due to the supply of fine particles along the slope and additional humidification, more eutrophic conditions were created and the intensity of soil degradation processes decreased. The thickness of the dark horizon of the buried soil is low (up to $10 \mathrm{~cm}$ ), due to erosion and to removal of material from elevated ground to the pits, where it was mixed with other horizons. The increased dampness in the pits contributed to the preservation of organic matter, resulting in the formation of a thick, dark-coloured horizon in the pit infills. The upper part of the pits is less humidified and therefore the relict organic matter here degraded and became lighter. This was promoted by the processes of podzolisation typical of the Late Holocene (Aleksandrovsky, Aleksandrovskaya 2005).

The G/15 consists of seven main pedological units (Fig. 7, Table 2):

$100-80 \mathrm{~cm}$ b.g.l. - glaciofluvial silty varigrained sand with gravel with ironic precipitation (B horizon);

$80-70 \mathrm{~cm}$ - brown silty sand with humic admixtures (B horizon with Early Neolithic cultural layer);

$70-65 \mathrm{~cm}$ - light grey silty sand with krotovinas (AB horizon with Middle and Late Neolithic cultural layer);

$65-60 \mathrm{~cm}$ - whitish-grey silty sand with krotovinas (AB horizon with Bronze Age cultural layer);

$60-50 \mathrm{~cm}-$ dark grey to black humic silty sand (Ah - humic horizon of buried soil with Early Middle Ages cultural layer);

$50-40 \mathrm{~cm}$ - layered clayey and silty sand with humic admixtures (Middle Ages slope deposits);

$40-0 \mathrm{~cm}$ - humic muddy sand (tillage diamicton and dump). 
The bottommost samples of the studied G/15 profile represent substratum deposits of the Weichselian (Valdai) kame. These glaciofluvial deposits consist mostly of vari-grained sands - the fraction between 1.32 and 2.32 phi $(0.4-0.2 \mathrm{~mm})$ ranges between 30 and $36 \%$. The percentage of coarsegrained sand and gravel (i.e. $<1 \mathrm{phi},>0.5 \mathrm{~mm}$ ) reaches up to $17.5 \%$ and of mud (i.e. $>3.32$ phi, $<0.1 \mathrm{~mm}$ ) - from 19 to $24 \%$. The grain-size distribution of these deposits is bimodal with three peaks: two sandy at 2 or $2.32(0.25$ or $0.2 \mathrm{~mm})$ and one silty 3.99 phi $(0.063 \mathrm{~mm})$. This demonstrates a short period of clastic material transportation and partial preservation of earlier traits of source deposits (probably of glacial origin). Glaciofluvial deposits are characterised by mean grain size of 2.13-2.33 phi (i.e. $0.20-0.23 \mathrm{~mm}$ ), sorting of 1.18 1.19 (i.e. poorly sorted) and symmetrical skewness. In the C-M diagram after Passega and Byramjee, these sediments are placed within Class I, which shows that they were transported by rolling and saltation (Passega, Byramjee 1969).

Table 2

Sertey II layer $\alpha$ : soil and sediment analyses: results of $\mathrm{B} / 15$ and $\mathrm{G} / 15$ profiles

\begin{tabular}{|c|c|c|c|c|}
\hline Description of horizons & $\begin{array}{c}\text { Depth } \\
\text { [cm b.g.l.] }\end{array}$ & $\begin{array}{c}\mathrm{pH} \\
\mathrm{H}_{2} \mathrm{O}\end{array}$ & $\begin{array}{l}\text { Organic Matter } \\
{[\%]}\end{array}$ & $\begin{array}{l}\mathrm{P}_{2} \mathrm{O}_{5} \\
{[\%]}\end{array}$ \\
\hline \multicolumn{5}{|c|}{ Sq. B/15 } \\
\hline A & $15-27$ & 5.9 & 0.90 & 0.14 \\
\hline $\begin{array}{l}\text { AB - slope deposits, Early Middle Ages pottery and re- } \\
\text { mains of dwelling in bottom }\end{array}$ & $27-42$ & 6.2 & 0.76 & 0.11 \\
\hline Ah - Bronze Age pottery & $42-48$ & 6.25 & 2.52 & 0.45 \\
\hline Ah - Late Neolithic pottery dominates & $48-65$ & 6.4 & 1.83 & 0.53 \\
\hline $\begin{array}{l}\text { AB - Late and Middle Neolithic pottery in upper part, } \\
\text { Early Neolithic pottery in lower part }\end{array}$ & $65-90$ & 6.3 & 0.54 & $\mathbf{0 . 3 3}$ \\
\hline B - glaciofluvial deposits & $90-120$ & 6.45 & 0.22 & 0.20 \\
\hline \multicolumn{5}{|c|}{ Sq. G/15 } \\
\hline AB - slope deposits & $30-40$ & & 4.09 & 0.18 \\
\hline AB - slope deposits, Middle Ages pottery & $40-50$ & & 2.87 & \\
\hline Ah - Early Middle Ages pottery & $50-60$ & & 3.59 & 0.50 \\
\hline AB - Bronze Ages pottery & $60-65$ & & 1.35 & 0.15 \\
\hline AB - Late and Middle Neolithic pottery & $65-70$ & & 1.48 & 0.18 \\
\hline Ah - Neolithic pit & 100 & & & $\mathbf{0 . 3 2}$ \\
\hline B - glaciofluvial deposits & $80-100$ & & $\begin{array}{l}0.80 \\
0.62\end{array}$ & \\
\hline
\end{tabular}

Traits similar to the substratum of glaciofluvial deposits can also be seen in the sedimentological characteristic of cultural layers. The mean grain size of deposits with cultural layers ranges from 2.12 to 2.25 phi $(0.21-0.23 \mathrm{~mm})$, sorting is 1.13-1.19 and the skewness remains symmetrical. However, the grain-size distribution of these deposits is trimodal with a further peak at 3 phi (i.e. $0.125 \mathrm{~mm}$ ). This demonstrates the growing role of a new depositional factor - most probably slope processes at the site - in the period of formation of the Neolithic and Bronze Age cultural layer. Subsequently, in the upper part of these deposits a soil humic horizon (Ah) developed up to the Early Middle Ages.
The textural traits of slope deposits that cover the medieval buried soil differ substantially from the characteristics of underlying deposits. This stratum is marked by a distinct increase in the mud fraction $(<0.1 \mathrm{~mm})$ admixture $-38-40 \%$, along with LOI (3-4\%). The deposits are composed mostly of silt (3.82-3.32 phi, 0.1-0.071 $\mathrm{mm}$ ) ranging $20.5-22.4 \%$. The mean grain size is 2.7 phi (i.e. $0.16 \mathrm{~mm}$ ), sorting - from 1.23 to 1.58 (poorly sorted) and the skewness ranges from -0.28 to -0.02 (coarse skewed to symmetrical). The described deposits can be recognised as "soil deluvium" according to Stochlak (1996) - i.e. slope wash deposits accumulated after the deforestation of an area, as a result of soil humic horizon erosion. In the very top part they pass into 
unstructured (massive) tillage diamicton after Sinkiewicz $(1995,1998)$ or "agricultural deluvia" after Stochlak $(1978,1996)$. These deposits could also (at least partly) originate from an artificial earthwork, meaning that they were accumulated as a result of intentional and direct human activity. This could explain the clear difference in textural traits, in comparison with underlying sediments.

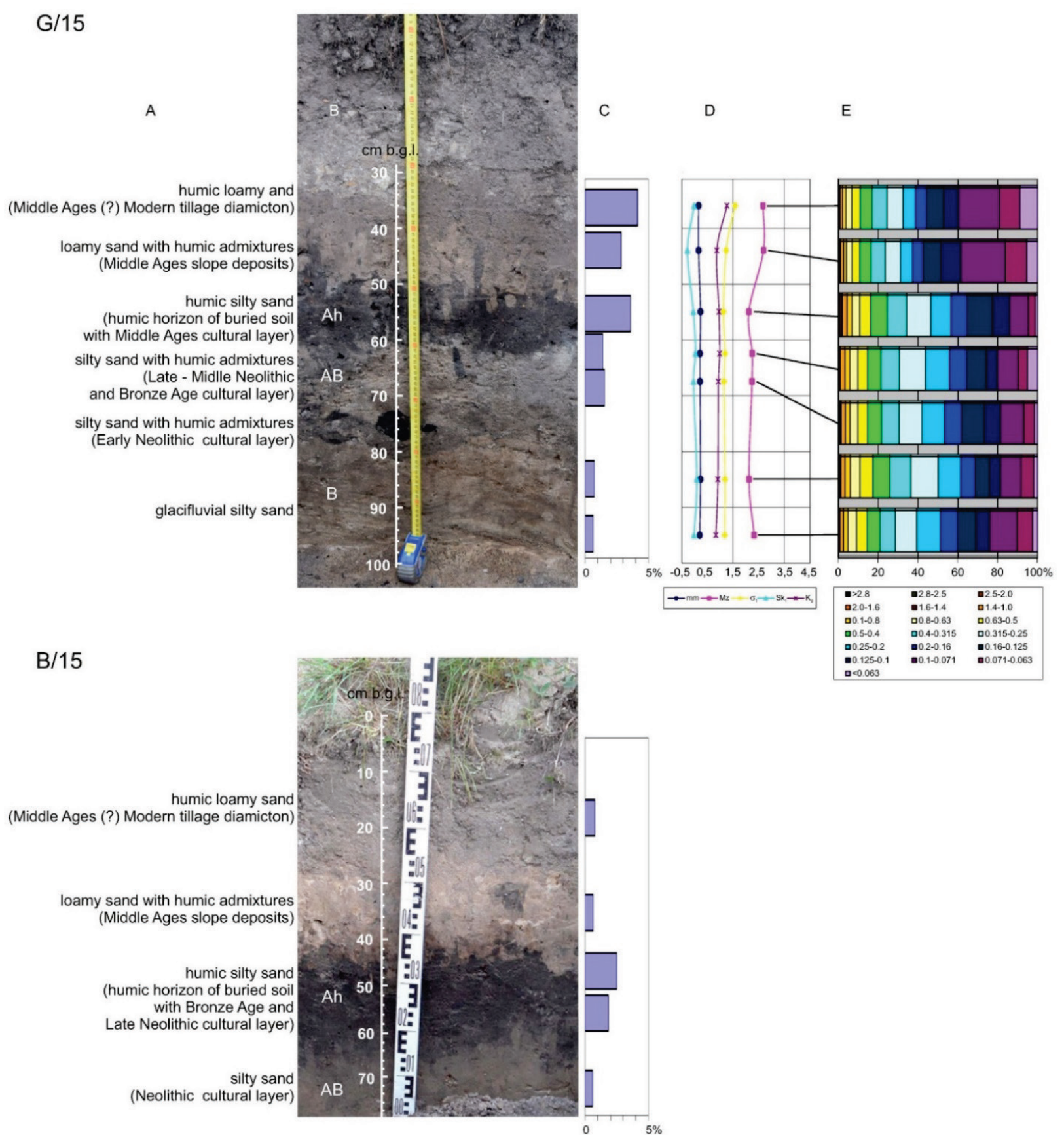

Fig. 7. Lithology of deposits of Serteya II layer $\alpha$ profile
A. Lithologic profile
B. Pedological horizons
C. Content of organic matter
D. Folk and Ward coefficients

$\mathrm{mm}$ - mean grain size [mm], $\mathrm{M}_{\mathrm{z}}$ - mean grain size [phi], $\sigma_{1}$ - sorting index, $\mathrm{Sk}_{1}-$ skewness, $\mathrm{K}_{\mathrm{g}}-$ kurtosis

E. Grain-size distribution 
Anthracological studies showed the presence of five taxa of trees and shrubs within deposits of the $\mathrm{G} / 15$ profile: Corylus avellana $\mathrm{L}$. hazel (eleven fragments), Alnus sp. alder (five fragments), Acer platanoides maple (three fragments) and one fragment each of Juniperus communis common juniper and Abies sp. fir. The taxonomic composition of the charcoals in individual samples is presented in Table 3. Both the number of fragments and taxonomic differentiation were very low. In the samples dated to the Middle and Late Neolithic (samples 9, 11, 16) only charcoals of hazel and alder were identified. In the Bronze Age layer (no. 7) single fragments of fir and juniper were found, and in the Early Medieval samples (no. 2,3) remains of hazel, maple and alder were discovered. Charcoals obtained from samples 3 and 16 were characterised by a smooth surface and rounded edges. In the case of a few fragments, in samples 3 and 7 , numerous radial cracks, local wood tissue burnout and traces of vitrification were found. In sample 16 the remains of branch wood occurred.

Table 3

Serteya II layer $\alpha$ : taxonomic spectrum of charcoals from G/15 profile

\begin{tabular}{|c|c|c|c|c|c|c|c|c|}
\hline \multirow[b]{2}{*}{ Sample No. } & \multirow{2}{*}{$\begin{array}{c}\text { Depth } \\
\text { [cm b.g.l.] }\end{array}$} & \multirow{2}{*}{$\begin{array}{c}\text { Soil } \\
\text { horizons }\end{array}$} & \multicolumn{5}{|c|}{ Number of charcoal fragments } & \multirow[b]{2}{*}{ Sum } \\
\hline & & & Abies sp. & $\begin{array}{c}\text { Acer } \\
\text { platanoides }\end{array}$ & Alnus sp. & $\begin{array}{l}\text { Corylus } \\
\text { avellana }\end{array}$ & $\begin{array}{l}\text { Juniperus } \\
\text { communis }\end{array}$ & \\
\hline 2 & \multirow{2}{*}{$50-60$} & \multirow{2}{*}{$\mathrm{Ah}$} & & & 2 & 6 & & 8 \\
\hline 3 & & & & 3 & & & & 3 \\
\hline 7 & $60-65$ & $\mathrm{AB}$ & 1 & & & & 1 & 2 \\
\hline 9 & \multirow{2}{*}{$65-70$} & \multirow{2}{*}{$\mathrm{AB}$} & & & 2 & 1 & & 3 \\
\hline 11 & & & & & 1 & & & 1 \\
\hline 16 & 100 & Neolithic pit & & & & 4 & & 4 \\
\hline
\end{tabular}

The presence of hazel and alder charcoals in Neolithic sediments reflects the widespread occurrence of these taxa in the upper Western Dvina River region during this period, as documented by pollen studies of Dolukhanov et al. (1989) and Tarasov et al. (2019). The importance of hazel shrubs for the economy of Neolithic communities at the Serteya II site has also been confirmed by previous research, which showed the use of hazelnuts as a food resource, and Corylus wood as material for the production of certain elements of pile-dwelling constructions (Mazurkevich et al. 2010). Wood charcoal fragments from the Neolithic pit were strongly smoothed and rounded, which in turn may suggest their displacement. According to Scott (2010), macroscopic charcoals may be transported over long distances, especially by slope wash processes.

The finding of Abies remnants in the sample attributed to the Bronze Age (no. 7) is a controversial discovery. The Serteya region is outside the modern range of the Abies genus. The closest to the studied region, but about $700 \mathrm{~km}$ from the site, is the north-eastern limit of the modern range of Abies alba in central Poland (Danielewicz 2012). According to Środon (1983), there is no reliable palaeobotanical evidence that would indicate a wider, north-eastern range of the common fir tree, including in earlier climatic periods. The most northerly range limit is that of A. siberica, but it occurs only in the eastern part of Russia (Bugała 1991; Podbielkowski 2002; Johnson 2014), over $1,500 \mathrm{~km}$ from the Serteya site. Due to the lack of other confirmed palaeobotanical reports on the appearance of Abies macroremains in the forest communities of the East European Plain, contamination of sample 7 by younger material may be suspected. Xylological data indicate that Abies alba wood was an item of intensive long-distance trade in early historical periods (e.g. Pukienè 2008; Cywa 2018 with further literature). The single fragment of juniper charcoal was determined in sample 7. As the site is located within the contemporary range of Juniperus communis (Benkowa, Schweingruber 2004; Hantemirova et al. 2012), the local provenience of its wood is probable, though pollen grains of juniper have not been recorded in local palynological diagrams (Dolukhanov et al. 1989, 2004; Tarasov et al. 2019; Kittel et al. 2020). The structure of both fragments from sample 7 is characterised by numerous radial cracks and local vitrification of tissues. Such fusions and fissures can be caused by rapid combustion at high temperatures (Marguerie, Hunot 2007; Barnett 2012). 
The B/15 consists of five units (Fig. 7, Table 2):

120-90 cm b.g.l. - glaciofluvial silty sand with ironic precipitation (B horizon);

90-65 cm - greyish brown silty sand with krotovinas (AB horizon with Late and Middle Neolithic cultural layer and Early Neolithic cultural layer in the bottom);

65-42 cm - dark grey to black humic silty sand (Ah - humic horizon of buried soil with Late Neolithic and Bronze Age cultural layer);

42-27 cm - light brown clayey-silty sand with humic admixtures (Middle Ages slope deposits);

$27-15 \mathrm{~cm}$ - grey and brown humic clayeysilty sand (tillage diamicton).

In section $\mathrm{B} / 15$, the cultural layer was found in the buried soil (Ah) with a thick (20-25 cm thick) dark-coloured humic horizon. A transition horizon $\mathrm{AB}(25 \mathrm{~cm})$ was recognised below, with a large number of krotovinas. It overlies a brown coloured B horizon, in which krotovinas were also identified. The total thickness of the humusrich part of the soil profile reaches $45-50 \mathrm{~cm}$. The development of this profile is associated with a long meadow stage, probably of anthropogenic character. The high content of charcoal, including dispersed particles, obviously results from human activity. Probably, it also led to a darkening of the colour of the cultural layer.

A dark humic (carbon-rich) Ah horizon is well represented here and covered only by slope deposits as well as a modern drainage dump from the reclamation canal. The process of podzolisation has changed only the upper part of the humic horizon. The lower part of the Ah horizon, containing archaeological material, and the lower AB horizon, typical of soils of unforested areas (grassland and meadow black earth) are well preserved; noteworthy is the large number of krotovinas. The silty composition of this buried soil contributes to the preservation of organic matter. The considered stage of soil formation can be correlated with a wide period (Atlantic - middle Subboreal) on the basis of archaeological finds.

Phosphate analysis was applied in studies of the cultural layers in profiles $\mathrm{G} / 15$ and B/15 (Table 2). Phosphorus is distinguished by its stability in soils and remains in the cultural layer for a long time (Velleste 1952; Hamond 1983). Much depends on the form in which phosphorus is present. When applying phosphorus fertiliser, it is quickly washed away. But the settlements may have stable forms, primarily apatite (calcium phosphate), which forms the basis of bone. It is stable in muddy soils and is quickly washed out of sandy soils.
The stability of phosphorus in the studied soils differs. In the section in square $\mathrm{B} / 15$, more phosphorus was preserved in a thick buried soil layer, where the content of clay is higher. In the eroded soil (section G/15) it is preserved only in the early-medieval buried soil, while in the Bronze Age and Neolithic Age layers its content is similar to that of substratum deposits.

\section{Discussion: sedimentological and post-depositional processes in the shore zone}

The sediments of the lower unit $(115-85 \mathrm{~cm}$ b.g.l.) - fine- and medium-grained sands with silt sands - were accumulated under various sedimentation conditions. Based on the distribution of samples on the mean grain size $\left(\mathrm{M}_{1}\right)$ and standard deviation $\left(\mathrm{M}_{2}\right)$ diagram (Fig. $2 \mathrm{~F}$ ), referring to the opinion of Sly et al. (1983), it can be concluded that they were deposited in upper flow regime conditions. Settlement velocity flow was on average $20 \mathrm{~cm} / \mathrm{s}$ and ranged from $13 \mathrm{~cm} / \mathrm{s}$ to $25 \mathrm{~cm} / \mathrm{s}$. The shear velocities of flow necessary for transport of the thickest grains were about $90 \mathrm{~cm} / \mathrm{s}$. Moreover, referring to the views of Mycielska-Dowgiałło and Ludwikowska-Kędzia (2011) and based on distribution of samples on the mean grain size $\left(M_{z}\right)$ versus sorting $\left(\sigma_{1}\right)$ diagram (Fig. $2 G$ ), they are river channel and bed lag alluvia, or glaciofluvial sediments. Having in mind the aforementioned considerations, and due to the relatively high content of organic matter (at the level of $4.85 \%$ ) and low content of lithophilic elements ( $\mathrm{Na}$ often below $0.1 \mathrm{mg} / \mathrm{g}$, $\mathrm{K}$ often below $0.5 \mathrm{mg} / \mathrm{g}$ and $\mathrm{Mg}$ often below $1 \mathrm{mg} / \mathrm{g}$ ) in these sediments, the deposits of the lower unit can be considered to be channel alluvia. Since the structure of the sediments of the lower sedimentation unit is deformed (Fig. 3), and they are located at the foot of the kame slope, it can be assumed that the sediments of this series were subsequently displaced as a result of slope wash processes. It must be stressed that slope wash processes were confirmed also for the $\mathrm{G} / 15$ profile in the Middle and Late Neolithic.

The results of palaeoecological analyses (both palaeobotanical and palaeozoological) demonstrate that the sediments from the depth between 115 and $106 \mathrm{~cm}$ b.g.l. in the L29 core contain species characteristic for shallow standing water, which indicates the nearby presence of a lake, as well as its possible episodic transgressions into the shore zone during periodic or seasonal increases in water level. After that, a rapid 
shallowing of the reservoir is observed together with an increase in clastic material inflow. The sharp border of the Fe/Mn (from 273 to 137) and $\mathrm{Cu} / \mathrm{Zn}$ (from 0.52 to 0.4 ) ratios also proves the sudden change in deposition environment. These sediments are enriched in lithophilic elements $(\mathrm{Na}, \mathrm{K}$ and $\mathrm{Mg}$ ), whereas the content of $\mathrm{Ca}$ is constant $(c a 4.5 \mathrm{mg} / \mathrm{g})$. The conclusion of the STII M25 core study, too, shows that a steady decrease in shallow water cover could have occurred in the studied area up to $c a 4150 \mathrm{BC}$. The Early Neolithic communities existed at the Serteya II layer $\alpha$ site as well as on the lake shore before $4150 \mathrm{BC}$. During this time, cultural layers were destroyed probably by slope processes and lake water transgressions. The most significant increase in water level was defined for the period between 4150 and $3600 \mathrm{BC}$ (Kittel et al. 2020). However, it did not reach the area of the L29 core (Fig. 3). Evidence of intense settlement activity in the lake shore zone (Sertya II-2 site) was recorded for the period $c a 4150-3250 \mathrm{BC}$ and denudation processes were active even until ca $2500 \mathrm{BC}$ (Kittel et al. 2020).

The micromorphological study of the stratigraphic sequence of the L29 monolith allows for more detailed assumptions regarding formation processes of the deposits in the palaeolake shore zone. The horizon described as organic mud (OM, $109-110 \mathrm{~cm}$ b.g.1.) consists mostly of terrestrial plant remains, many horizontally aligned, and detritus (Fig. 4A), with single fine charcoal fragments. It may represent the natural accumulation of organic material in the transition zone between the lake and land, but anthropogenic settlement activities, too, should be taken into account as a primary forming factor, as in the case of similar contexts (albeit with more numerous and differentiated anthropogenic inclusions) investigated at Lake Luokesa (Lithuania) and several Swiss lakeshore sites (Ismail-Meyer et al. 2013; IsmailMeyer 2014). The relatively good state of preservation of the plant remains and only limited presence of soil fauna excrements (mites) indicate a considerably high accumulation rate, rapid burial and generally waterlogged conditions $(\mathrm{Fe} / \mathrm{Mn}$ ratio above 280 and $\mathrm{Ca} / \mathrm{Fe}$ ratio above 1.5 ) of the deposit at the depth $109-110 \mathrm{~cm}$ b.g.l. of the L29 core sequence.

The SOM layer $(96 / 100-109 \mathrm{~cm})$ is composed of moderately-well sorted sand, plant remains (many horizontally aligned, Fig. 4B), detritus and single charcoal and bone fragments. It also includes a poorly-moderately sorted "mixed" zone, juxtaposed with the original, undisturbed microfabric; the majority of anthropogenic inclusions are found within this zone, along with occasional angular clay-rich soil fragments (Fig. 4B, $\mathrm{C}$ ), similar to material building the OSOM (see below). A combination of inland and littoral factors may have been responsible for the formation of the SOM: erosion of the upper sandy slopes of the kame and the resulting sedimentation of runoff downslope have to be considered (Ismail-Meyer et al. 2013; Ismail-Meyer 2014). Also, the possibility that both the OM and SOM may have been (re)worked by episodic increases in the lake water level should be acknowledged, although no diatoms and only single sponge spicules were discovered. On the one hand, this would include the input of fine sand and detrital material, and, on the other hand, the possibility of the removal (truncation) of certain parts of the OM-SOM sequence (Karkanas et al. 2011; Ismail-Meyer et al. 2013). The coarser (medium, coarse) sand horizon at $c a 105 \mathrm{~cm} \mathrm{b.g.l.} \mathrm{is} \mathrm{potentially} \mathrm{a} \mathrm{sign} \mathrm{of} \mathrm{an}$ erosion surface in the lake shore zone.

Neither the OM nor SOM unit was formed in a subaqueous environment, as no laminations or bedding of silt and sand were observed (see: Karkanas et al. 2011; Stahlschmidt et al. 2015), but they remained largely waterlogged, which ensured good preservation of plant remains. At least periodic drying of the uppermost part of the SOM, at its microscopically gradual interface with the overlying OSOM horizon, is indicated by the presence at this depth of redoximorphic features (Vepraskas et al. 2018). The highest concentrations of $\mathrm{Fe}$ (above $12 \mathrm{mg} / \mathrm{g}$ ) are double the values from the lower part of the profile, and moreover, they correlate with catchment erosion index $(\mathrm{Na}+\mathrm{K}+\mathrm{Mg} / \mathrm{Ca}$ from 3.2 to 4.3). Among them is a horizontal Fe/Mn-rich "crust" (Fig. 4D) formed at $c a 100 \mathrm{~cm}$ b.g.1., the continuity of which appears to be vertically cut by the edge of the "mixed" zone. In thin section, the mixed zone has a defined, (sub)angular shape, with vertical and oblique boundaries. Apart from single anthropogenic materials, the "mixed microfabric" includes randomly oriented and distributed mineral grains (also coarse and medium), few plant remains, detritus and occasional angular fragments of clayrich crusts/soil, of the kind found in-situ in the overlying OSOM (Fig. 4B, C, E, F). The issue of whether these signs of reworking (mixing) are related to natural causes (e.g. bioturbation, deformation) or anthropogenic activity (e.g. digging) (Deák et al. 2017; Krupski et al. 2017), remains unclear at the moment. A similar feature was identified by Karkanas et al. (2018) and inter- 
preted as oxidised surface crust disturbed possibly by trampling.

Again, a significant increase in the palaeolake water level took place $c a 2300-2200 \mathrm{BC}$ and later regression occurred (Kittel et al. 2020). The coarse detritus gyttja layer in the STII M25 core that accumulated in that time is interlaminated in the L29 core (at 100-83 cm b.g.l.) with muddy sand with organic matter, characterised by an enrichment in $\mathrm{Fe}$ and lithophilic elements in relation to Ca content (Fig. 2). The deposition of muddy sand with organic matter unit started shortly before 2000-1900 BC, as confirmed by the ${ }^{14} \mathrm{C}$ date of plant macrofossils from the depth of $95 \mathrm{~cm} \mathrm{b.g.l.}$ This demonstrates that the lacustrine environment could periodically (e.g. during spring floodings) reach the L29 area $c a$ 2300-2200 BC, as suggested by the palaeoecological proxies, mostly subfossil Cladoceran remains. In the later period, regression occurred again. From 2100 BC onwards, only short seasonal (spring) floodings with eutrophic water cover $c a$ 2000-1900 BC were recorded in the STII M25 core (Kittel et al. 2020). In that period, a few chironomid head capsules representing three taxa (Paratanytarsus austriacus-type, Pseudochironomus-type and Tanytarsus pallidicornis-type) were recorded in the L29 (only at a depth of $87.5 \mathrm{~cm}$ ) that are typical of stagnant and flowing waters in the European lowlands (Giłka 1999, 2011). At the same depth, the presence of Cristatella mucedo, usually found in lakes with a constant water level, confirms these observations (Økland, Økland 2000). The presence of midge subfossils in the layer of muddy sand with organic matter, coincides with incidental chironomids and bryozoan occurrence in nearby M25 (Kittel et al. 2020). Because the concentration of subfossils is very low (Fig. 6), it does not indicate the presence of a permanent water body. Such episodic aquatic midge records reveal periodic (seasonal) inundation of area L29. The local palaeogeographical situation, along with recorded chironomids' taxa phenology (Giłka 1999, 2011), suggests that L29 inundation took place during the spring season, when the water level of Serteyka River increased due to snow thawing and fed the palaeolake in the Serteya II site area. Simultaneously, melting snow waters encouraged slope wash processes.

The clayey and silty sand with organic matter sequence recognised from $100 / 96$ to $80 \mathrm{~cm}$ b.g.l. (OSOM unit) is characterised by more developed types of microstructure as compared to the OM and SOM. The moderately sorted mineral grains are bridged and coated/capped by the fine fraction
$(<2 \mu \mathrm{m})$ (Fig. 4E) or embedded in a dusty clay matrix (in the uppermost $3 \mathrm{~cm}$ ) (Fig. 4F). The plant remains are less numerous and more poorly preserved, but there are more punctuations and silt-sized detritus (within the clay), phytoliths, diatoms, and sponge spicules, as well as anthropogenic inclusions such as charcoal and bone fragments (also burnt). Considering the location of the L29 profile, these traits are consistent with a gradual build-up of deposits in a series of events that involved sedimentation of suspended material. Clay and organic matter laminae/crusts recognised locally may indicate surfaces created by individual flooding episodes. Some of these features include anthropogenic inclusions (Fig. 4E), which suggests that at least some of the artefacts within the OSOM may have been "brought" by the waters, as a result of flooding and/or slope wash processes.

The inflow of clastic material into the nearby lake reservoir is indicated by palaeoecological proxies. The vertical fluctuations of the $\mathrm{Na}+\mathrm{K}+$ $+\mathrm{Mg} / \mathrm{Ca}$ ratio, too, suggest periodic input of mineral matter from the catchment. Apart from shortterm variations, a general increase in the catchment erosion indicator (to a value of 8.86) indicates a gradual increase in mechanical denudation near the reservoir. From a sedimentological point of view, the origin of sediments in the roof of lower sedimentation unit ( $\mathrm{ca} 100-85 \mathrm{~cm}$ b.g.l.) can be interpreted as having accumulated in the littoral zone of the lake. According to Teisseyre (1988), these sediments are similar in texture to flood alluvia deposited in sub-aquatic conditions. Moreover, some of the clayey silty sands of deformed structure located at this depth can be considered to be deluvium deposited in a lake shore zone. The period of higher mechanical denudation corresponds with a decrease in the $\mathrm{Ca} / \mathrm{Fe}$ ratio. The described geochemical stratification may be the result of a wetter climate phase and nutrient delivery due to wildfires in the catchment (Pleskot et al. 2018).

During the phases of inundation (flooding episodes) the reduction in $\mathrm{Fe} / \mathrm{Mn}$ caused local gleying (Fig. 4G); the dispersion (deflocculation) of surface material also occurred, enabling downward movement of clay with organic matter particles (Fig. 4H) and silt after the waters had disappeared (Macphail et al. 2010; Vepraskas et al. 2018). This process was enhanced upon desiccation of the sediments, which resulted in the formation of cracks and "opening" of the deposits' structure (Kühn et al. 2018). Further alterations indicate aerial exposure of the mudflats and their 
subsequent drying - well visible are redoximorphic features, among them the replacement (pseudomorphosis) of organic matter (redeposited plant remains, roots in situ, detritus within clay laminae) with iron/manganese oxides (Fig. 4E, G, $\mathrm{H})$, as well as signs of soil fauna activity (Fig. $4 \mathrm{H}$ ) and plant growth (Macphail et al. 2010; IsmailMeyer et al. 2013; Karkanas et al. 2018).

The period after $c a 1700 \mathrm{BC}$ is characterised by the process of natural succession of the lake towards a wetland in the STII M25 core. An intensification of slope processes occurred between ca $1850 \mathrm{BC}$ and $c a 1600 \mathrm{BC}$ (Kittel et al. 2020), as a result of activity of the Bronze Age Textile Ceramics Culture communities in the first half of the $2^{\text {nd }}$ mill. $\mathrm{BC}$, on the kame surface at the Serteya II layer $\alpha$ site. The slope wash processes were documented in the G/15 profile for the Late Neolithic and Bronze Age and the intense inflow of clastic material is recorded in palaeo-ecological proxies in the L29 core.

Well-developed krotovinas indicate the genetic similarity of the buried soil recognised in both the G/15 and the B/15 profiles. Probably, erosion essentially affected the soil profile, and it is possible that the cultural layer was not only partially washed away, but also partly redeposited. As a result, the Bronze Age and Neolithic cultural layers are thin in the $\mathrm{B} / 15$ profile, $c a 5 \mathrm{~cm}$ each, as is the overlying dark humic horizon of the Late Neolithic and Bronze Age buried soil. The results of a palaeopedological study of the $\mathrm{B} / 15$ profile led to the conclusion that the Serteya II layer $\alpha$ site area could have been used for agriculture in the Late Neolithic and Bronze Age, as evidenced by Tarasov et al. (2019; cf. however, Kittel et al. 2020). Due to the light sandy composition, these soils could have been cultivated easily in that period, while the adjacent areas, located on higher surfaces composed of moraine, were difficult for cultivation using the tools available at the time. Deforestation (confirmed also by palaeobotanical results) and extensive agriculture (traced by Tarasov et al. 2019) resulted in the creation of conditions suitable for slope wash processes on the slightly inclined silty sand surface.

In the top of the Bronze Age deluvium, a soil humic horizon formed until the Early Middle Ages in the G/15 profile. In the L29 core, the deposits of the upper sedimentation unit, i.e. silty sands with organic matter $(85-65 \mathrm{~cm}$ b.g.l.), were accumulated under the conditions of a lower flow regime (Fig. 2), with an average settlement velocity of water flow of about $13 \mathrm{~cm} / \mathrm{s}$. Referring to the views of Mycielska-Dowgiałło and Ludwi-
kowska-Kędzia (2011), based on the distribution of samples on the mean grain size $\left(\mathrm{M}_{\mathrm{z}}\right)$ versus sorting $\left(\sigma_{1}\right)$ diagram (Fig. 2G), it can be considered that they are overbank alluvia. The ${ }^{14} \mathrm{C}$ date set demonstrates that a fluvial system finally replaced the lacustrine system in the site area, and overbank deposition started between 300 and 1300 AD (Kittel et al. 2020). The terrestrialisation process and only semi-permanent water body occurrence are confirmed in our palaeozoological record, mostly recorded in Cladoceran remains. The intense inflow of clastic material suggests landscape openness of the site environment. From the Early Medieval layer in the G/15 profile, 11 fragments of well-preserved charcoals of alder, maple and ash were obtained, but only Acer platanoides charcoals had burnout traces and a few radial cracks. The intense human impact in Early Middle Ages Serteya II site area is evidenced by Tarasov et al. (2019) and also by new results by A. Hrynowiecka (pers. comm.).

\section{Conclusions}

Detailed analysis of lithological profiles and the archaeological context allowed for an understanding of Mid- and Late Holocene natural landscape evolution and human-environment relationships in a palaeolake shore zone of a recently glaciated area in the East European Plain. The geomorphological processes were highly influenced by lacustrine, slope and fluvial systems along with episodic human impact. All the changes that occurred are of natural, mostly climatic origin, but human impact on formation processes of deposits in the palaeolake shore zone is clearly visible and resulted in anthropogenic deposition and an acceleration of slope processes. The main phases of land relief formation in the Serteya II site shore zone (close to the STII L29 core) can be summarised as follows:

1. Mesolithic, Early- to Mid-Neolithic (from ca $9500 \mathrm{BC}$ to $2300 \mathrm{BC}$ ) - natural accumulation of minerogenic and organic material in the transition zone between the lake and land, fluctuations in lake water level (inflow of minerogenic material, wave erosion), periodic drying; possible anthropogenic settlement activities; signs of slope processes from the Mid-Neolithic;

2. Ca $2300 \mathrm{BC}$ - desiccation after the deposition of sediments at $115-100 \mathrm{~cm}$ in the L29 core; 
3. Late Neolithic ( ca 2300-2200 BC) - palaeolake water level increase; beginning of clayey silty sands with organic matter deposition;

4. Late Neolithic, Bronze Age ( ca 22001500 BC) - successive deposition of muddy sands with organic matter (and anthropogenic inclusions) in the shore zone, during seasonal (springthaw) floods; stagnation of flood waters in shallow basins, subsequent drying-up of sediments followed by floral and faunal activity; possible slope wash processes resulting from snow melting in the area transformed by human activity;

5. Between $c a 1500 \mathrm{BC}$ and $c a 400 \mathrm{AD}$ - palaeolake regression, wetland development;

6. Middle Ages (after 400 AD) - overbank deposition; intense human impact;

7. A small area with fertile and open lands was located near the Neolithic-Middle Age settlement, which was possibly used for agricultural/cattle-breeding activities. Such anthropogenic influence may also be indicated by strong deforestation, which intensified slope processes.

Summarising, we want to stress that our results are the outcome of a geoarchaeological study, undertaken in strict cooperation with archaeological research already at the fieldwork stage. The reconstruction of complex conditions leading to the deposition of sediments in the palaeolake shore zone was possible only with the use of comprehensive palaeoenvironmental analyses of biotic remains and geochemical and sedimentological traits, as well as a pedological study with a very important role played by micromorphological analysis of deposits in the L29 core.

\section{Acknowledgments}

The palaeoecological research at Serteya II site is financed by grants from the "National Science Centre, Poland" based on the decision No. 2017/25/B/HS3/00274. Archaeological research was supported by a grant of the Russian Science Foundation (project "Lacustrine sites of the $4^{\text {th }}-3^{\text {rd }}$ mill. $\mathrm{BC}-$ the origins and development of pile-dwelling settlements phenomenon in NW Russia” №19-78-00009). The palaeobotanical analysis was supported by the W. Szafer Institute of Botany, Polish Academy of Sciences, from its statutory funds. The soil micromorphological observations were carried out at the Institute of Soil Science and Environmental Protection, Wrocław University of Environmental and Life Sciences, by kind permission of Prof. C. Kabała. We are indebted to J. Tomkowiak for help with geochemical sample processing. We also thank Ph.D. M.
Płóciennik for his discussion and comments on our results.

\section{References}

Aleksandrovsky A.L., Aleksandrovskaya E.I. 2005. Evolyutsiya pochv i geograficheskaya sreda. Nauka, Moskva.

Andersen T., Cranston P., Epler J. 2013. Chironomidae of the Holarctic Region: Keys and Diagnoses. Part 1. Larvae. Insect Syst. Evol. Suppl. 66, Scandinavian Entomology Ltd., Lund.

Barnett C. 2012. Additional specialist report "Environmental Wood charcoal" to the publication Suburban Life in Roman Durnovaria: Excavations at the Former County Hospital Site, Dorchester 2000-2001 by Mike Trevarthen, Wessex Archaeology; http://www.wessexarch.co.uk/files/ projects/dorchester_county_hospital/02_Charcoal.pdf [available at 25.02.2012].

Bengtsson L., Enell M. 1986. Chemical analysis. In: B.E. Berglund (ed.) Handbook of Holocene Palaeoecology and Palaeohydrology. John Wiley and Sons ltd., Chichester: 423-451.

Benkova V.E., Schweingruber F.H. 2004. Anatomy of Russian Woods. Haupt Verlag, Wien.

Brooks S.J., Heiri O., Langdon P.G. 2007. The identification and use of palaearctic chironomidae larvae in palaeoecology. Quaternary Research Association, London.

Berggren G. 1969. Atlas of seeds and small fruits of Northwest-European plant species with morphological descriptions. Part 2. Cyperaceae. Swedish Nat. Sci. Res. Council, Stockholm.

Bjerring R., Becares E., Declerck S., Gross E.M., Hansson L.A., Kairesalo T., Nykänen M., Halkiewicz A., Kornijów R., Conde-Porcuna J.M., Seferlis M., Nõges T., Moss B., Amsinck S.L., Odgaard B.V., Jeppesen E. 2009. Subfossil Cladocera in relation to contemporary environmental variables in 54 Pan-European lakes. Freshwater Biology 54: 2401-2417.

Bugała W. 1991. Drzewa i krzewy dla terenów zieleni. Państwowe Wydawnictwo Rolnicze i Leśne, Warszawa.

Bullock P., Fedoroff N., Jongerius A., Stoops G., Tursina T. 1985. Handbook for soil thin section description. Waine Research, Wolverhampton.

Buskens R. 1987. The chironomid assemblages in shallow lentic waters differing in acidity, buffering capacity and trophic level in the Netherlands. Entomologica Scandinavica, Suppl. 29: 217-224.

Cappers R.T.J., Bekker R.M., Jans J.E.A. 2006. Digital seed atlas of the Netherlands. Barkhuis/Groningen University Library, Groningen.

Courty M., Goldberg P., Macphail R. 1989. Soils and Micromorphology in Archaeology. Cambridge University Press, Cambridge. 
Cywa K. 2018. Uwarunkowania doboru surowca drzewnego w polskich grodach i ośrodkach wczesnomiejskich w średniowieczu - analiza ksylologiczna przedmiotów użytkowych. (Unpublished doctoral dissertation). Instytut Botaniki im. Władysława Szafera Polskiej Akademii Nauk, Kraków.

Danielewicz W. 2012. Drzewa leśne Polski. In: W. Matuszkiewicz, P. Sikorski, W. Szwed, M. Wierzba (eds) Zbiorowiska roślinne Polski. Lasy i zarośla. Ilustrowany przewodnik. Wydawnictwo Naukowe PWN, Warszawa: 21-62.

Deák J., Gebhardt A., Lewis H., Usai M.R., Lee H. 2017. Soils disturbed by vegetation clearance and tillage. In: C. Nicosia, G. Stoops (eds) Archaeological Soil and Sediment Micromorphology. Wiley-Blackwell: 233-264.

Dolukhanov P.M., Gey N.A., Miklyayev A.M., Mazurkevich A.N. 1989. Rudnya-Serteyska, A stratified dwelling-site in the upper Duna basin (a multidisciplinary research). Fennoscandia Archaeologica 6: 23-27.

Dolukhanov P., Shukurov K., Arslanov A.N., Mazurkevich L.A., Savel'eva E.N., Dzinoridze M.A., Kulkova M., Zaitseva G.I. 2004. The Holocene Environment and Transition to Agriculture in Boreal Russia (Serteya Valley Case Study). Internet Archaeology 17, http://intarch.ac.uk/journal/issue 17

Frey D.G. 1986. Cladocera analysis. John Wiley \& Sons Ltd.

Folk R.L., Ward W. 1957. Brazos River bar: A study in the significance of grain size parameters. Journal of Sedimentary Petrology 27: 3-26.

Giłka W. 1999. Sezonowa dynamika pojawu wybranych gatunków ochotkowatych z plemienia Tanytarsini Pojezierza Kaszubskiego (Diptera: Chironomidae). Acta Entomologica Silesiana 7/8: 31-42.

Giłka W. 2011. Analiza różnorodności faunistycznej ochotkowatych z plemienia Tanytarsini w Europie (Diptera: Chironomidae). DIPTERON, 27: 11-31.

Ginzburg K.E. 1981. Fozfor osnovnykh tipov pochv SSSR. Nauka, Moskva.

Goldberg P., Macphail R. 2006. Practical and Theoretical Geoarchaeology. Wiley-Blackwell.

Grimm E.C. 1987. CONISS: a FORTRAN 77 program for stratigraphically constrained cluster analysis by the method of incremental sum of squares. Computers \& Geosciences 13: 13-35.

Grimm E.C. 2016. TiliaIT. Available at https://www.tiliait.com/

Hamond F.W. 1983. Phosphate analysis of archaeological sediments. In: Landscape Archeology in Ireland. Oxford. BAR British Series. Vol. 116: 4780.

Hantemirova E.V., Berkutenko A.N., Semerikov V.L. 2012. Systematics and gene geography of
Juniperus communis inferred from isoenzyme data. Russian Journal of Genetics 48(9): 920926.

Ismail-Meyer K. 2014. The potential of micromorphology for interpreting sedimentation processes in wetland sites: a case study of a Late Bronzeearly Iron Age lakeshore settlement at Lake Luokesa (Lithuania). Vegetation History and Archaeobotany 23: 367-382.

Ismail-Meyer K., Rentzel P., Wiemann P. 2013. Neolithic Lakeshore Settlements in Switzerland: New Insights on Site Formation Processes from Micromorphology. Geoarchaeology: An International Journal 28: 317-339.

Jeppesen E., Christoffersen K., Landkildehus F., Lauridsen T., Amsinck S. L., Riget F., Søndergaard M. 2001. Fish and crustaceans in northeast Greenland lakes with special emphasis on interactions between Arctic charr (Salvelinus alpinus), Lepidurus arcticus and benthic chydorids. Hydrobiologia 442: 329-337.

Johnson O. 2014. Przewodnik Collinsa Drzewa. Multico Oficyna Wydawnicza, Warszawa.

Karkanas P., Pavlopoulos K., Kouli K., Ntinou M., Tsartsidou G., Facorellis Y., Tsourou T. 2011. Palaeoenvironments and Site Formation Processes at the Neolithic Lakeside Settlement of Dispilio, Kastoria, Northern Greece. Geoarchaeology: An International Journal 26: 83-117.

Karkanas P., Tourloukis V., Thompson N., Giusti D., Panagopoulou E., Harvati K. 2018. Sedimentology and micromorphology of the Lower Palaeolithic lakeshore site Marathousa 1, Megalopolis basin, Greece. Quaternary International 497: 123-136.

Kittel P., Mazurkevich A., Dolbunova E., Kazakov E., Mroczkowska A., Pavlovskaia E., Piech W., Płóciennik M., Sikora J., Teltevskaya Y., Wieckowska-Lüth M. 2018. Palaeoenvironmental reconstructions for the Neolithic pile-dwelling Serteya II site case study, Western Russia. Acta Geographica Lodziensia 107: 191-213.

Kittel P., Mazurkevich A., Wieckowska-Lüth M., Pawłowski D., Dolbunova E., Gauthier E., Krąpiec M., Maigrot Y., Danger M., Mroczkowska A., Okupny D., Płóciennik M., Szmańda J., Thiebaut E., Słowiński M. 2020 (in press.) On the border between land and water: the environmental conditions of the Neolithic occupation from 4.3 until $1.6 \mathrm{ka} \mathrm{BC}$ at Serteya, Western Russia. Geoarchaeology an Interdisciplinary Journal.

Koster E.H. 1978. Transverse rib: their characteristics, origin and paleohydrologic significance. In: A.D. Miall (ed.) Fluvial sedimentology. Canadian Society of Petroleum Geologists Memoir 5: 161-186.

Krupski M., Kabala C., Sady A., Gliński R., Wojcieszak J. 2017. Double- and triple-depth digging and Anthrosol formation in a medieval and 
modern-era city (Wrocław, SW Poland). Geoarchaeological research on past horticultural practices. Catena 153: 9-20.

Kühn P., Aguilar J., Miedema R., Bronnikova M. 2018. Textural Pedofeatures and Related Horizons. In: G. Stoops, V. Marcelino, F. Mees (eds) Interpretation of micromorphological features of soils and regoliths. Elsevier: 377423.

Macphail R.I., Allen M.J., Crowther J., Cruise G.M., Whittaker J.E. 2010. Marine inundation: Effects on archaeological features, materials, sediments and soils. Quaternary International 214: 44-55.

Marguerie D., Hunot J.Y. 2007. Charcoal analysis and dendrology: data from archaeological sites in north-western France. Journal of Archaeological Science 34: 1417-1433.

Mazurkevich A.N., Dolbunova E.V., Maigrot Y., Hookk D. 2010. Results of underwater excavations of Serteya II and research of pile-dwellings in Northwest Russia. Archaeologia Baltica 14: 47-64.

Mazurkevich A., Dolbunova E., Kittel P., Fassbender J., Maigrot Y., Mroczkowska A., Płóciennik M., Sikora J., Słowiński M., Sablin M., Shirobokov I. 2017. Multi-disciplinary research on the Neolithic pile-dwelling Serteya II site (Western Russia) and the landscape reconstruction. In: A. Marciniak-Kajzer, A. Andrzejewski, A. Golański, S. Rzepecki (eds) Nie tylko krzemienie. Not only flints. Instytut Archeologii Uniwersytetu Łódzkiego, Łódzka Fundacja Badań Naukowych, Stowarzyszenie Naukowe Archeologów Polskich Oddział w Łodzi, Łódź: 103-128.

Mazurkevich A., Kittel P., Maigrot Y., Dolbunova E., Mroczkowska A., Wieckowska-Lüth M., Piech W. 2020. Natural and anthropogenic impact on the formation of archaeological layers in a lake shore area: case study from the Serteya II site, Western Russia. Acta Geographica Lodziensia 110: 81-102.

Moller Pillot H.K.M. 2009. Chironomidae larvae. Biology and Ecology of the Chironomini. KNNV Publishing, Zeist.

Mycielska-Dowgiałło E., Ludwikowska-Kędzia M. 2011. Alternative interpretations of grain-size data from Quaternary deposits. Geologos 17,4: 189-203.

Nalepka D., Walanus A. 2003. Data processing in pollen analysis. Acta Palaeobotanica 43: 125-134.

Nicosia C., Stoops G. (eds) 2017. Archaeological Soil and Sediment Micromorphology. John Wiley \& Sons, Oxford.

Nolte U. 1989. Observations on neotropical rainpools (Bolivia) with emphasis on Chironomidae (Diptera). Studies on Neotropical Fauna and Environment 24: 105-120.
Økland K.A., Økland J. 2000. Freshwater bryozoans (Bryozoa) of Norway: Distribution and ecology of Cristatella mucedo and Paludicella articulata. Hydrobiologia 421(1-3): 1-24.

Passega R. 1964. Grain size representation by CM patterns as a geological tool. Journal of Sedimentary Petrology 34: 830-847.

Passega R., Byramjee R. 1969. Grain size image of clastic deposits. Sedimentology 13: 830-847.

Pawłowski D., Gruszka B., Gallas H., Petera-Zganiacz J. 2013. Changes in the biota and sediments of glacial Lake Koźmin, Poland, during the late Saalian (Illinoian). Journal of Paleolimnology 49: 679-696.

Pawłowski D., Borówka R.K., Kowalewski G.A., Luoto T.P., Milecka K., Nevalainen L., Okupny D., Zieliński T., Tomkowiak J. 2016. Late Weichselian and Holocene record of the paleoenvironmental changes in a small river valley in Central Poland. Quaternary Science Review 135: 24-40.

Pinder L.C.V. 1983. The larvae of Chironominae (Diptera: Chironomidae) of the Holarctic regionKeys and diagnoses. Chironomidae of the Holarctic Region. Keys and Diagnoses, 1. Larvae, Entomol. Scand. Suppl. 19: 149-294.

Pleskot K., Tjallingii R., Makohonienko M., Nowaczyk N., Szczuciński W. 2018. Holocene paleohydrological reconstruntion of Lake Strzeszyńskie (western Poland) and its implications for the central European climatic transition zone. Journal of Paleolimnology 59: 443459.

Podbielkowski Z. 2002. Fitogeografia części świata, Europa, Azja, Afryka, tom 1. Wydawnictwo Naukowe PWN, Warszawa.

Pukienė R. 2008. Vilniaus Žemutinès pilies XIII - XVI a radinių medienos rūšys. Lietuvos pilys 4: 95 111.

Rühle E. (ed.) 1973. Metodyka badań osadów czwartorzędowych. Wydawnictwo Geologiczne, Warszawa.

Schweingruber F.H. 1978. Mikroskopische Holzanatomie. Zürcher AG, Zug.

Scott A.C. 2010. Charcoal recognition, taphonomy and uses in palaeoenvironmental analysis. Palaeogeography, Palaeoclimatology, Palaeoecology 291: 11-39.

Sinkiewicz M. 1995. Przeobrażenia rzeźby terenu i gleb w okolicy Biskupina wskutek denudacji antropogenicznej. In: W. Niewiarowski (ed.) Zarys zmian środowiska geograficznego okolic Biskupina pod wplywem czynników natural$n y c h i$ antropogenicznych $w$ późnym glacjale $i$ holocenie. Oficyna Wydawnicza "Turpress", Toruń: 281-290.

Sinkiewicz M. 1998. Rozwój denudacji antropogenicznej w środkowej części Polski północnej. Uniwersytet Mikołaja Kopernika, Torun. 
Sly P.G., Thomas R.L., Pelletier B.R. 1983. Interpretation of moment measures derived from waterlain sediments. Sedimentology 30: 219-233.

Stahlschmidt M.C., Miller C.E., Ligouis B., Goldberg P., Berna F., Urban B., Conard N.J. 2015. The depositional environments of Schöningen 13 II4 and their archaeological implications. Journal of Human Evolution 89: 71-91.

Stochlak J. 1978. Struktury i tekstury młodoplejstoceńskich osadów deluwialnych. Biuletyn Instytutu Geologicznego 306: 115-174.

Stochlak J. 1996. Osady deluwialne nieodłączny efekt procesu spłukiwania i propozycja ich podziału. In: A. Józefciuk (ed.) Ochrona agroekosystemów zagrożonych erozją: ogólnopolskie sympozjum naukowe. Puławy - Lublin - Zwierzyniec, 11-13 września 1996 r., Prace Naukowe, Część 2, Puławy: 111-132.

Stoops G. 2003. Guidelines for Analysis and Description of Soil and Regolith Thin Sections. Soil Science Society of America, Madison.

Sundborg A. 1967. Some Aspects on Fluvial Sediments and Fluvial Morphology I. General Views and Graphic Methods. Landscape and Processes: Essays in Geomorphology. Geografiska Annaler 49(2-4): 333-343.

Szeroczyńska K., Sarmaja-Korjonen K. 2007. Atlas of subfossil Cladocera from Central and Northern Europe. Friends of the Lower Vistula Society.

Środoń A. 1983. Jodła pospolita w historii naszych lasów. In: S. Białobok (ed.) Jodła pospolita Abies alba Mill. Nasze Drzewa Leśne 4. Instytut Dendrologii, Polska Akademia Nauk, Państwowe Wydawnictwo Naukowe, WarszawaPoznań: 9-39.
Tarasov P.E., Savelieva L.A., Long T., Leipe C. 2019. Postglacial vegetation and climate history and traces of early human impact and agriculture in the present-day cool mixed forest zone of European Russia. Quaternary International 516: 21-41.

Teisseyre A.K. 1988. Mady dolin sudeckich. Cz. III: Subarealnie i subakwalnie deponowane osady pozakorytowe w świetle eksperymentu terenowego (1977-1979). Geologia Sudetica 23,2: 155.

Velichkevich F.Yu., Zastawniak E. 2006. Atlas of the Pleistocene vascular plant macrofossils of Central and Eastern Europe. Part 1 - Pteridophytes and monocotyledons. W. Szafer Institute of Botany, Polish Academy of Sciences, Kraków.

Velichkevich F.Yu., Zastawniak E. 2008. Atlas of the Pleistocene vascular plant macrofossils of Central and Eastern Europe. Part 2 - Herbaceous dicotyledons. W. Szafer Institute of Botany, Polish Academy of Sciences, Kraków.

Velleste L. 1952. Analiz fosfatnykh soyedineniy pochvy dlya ustanovleniya mest drevnikh poseleniy. Kratkiye Soobshcheniya Instituta Istorii Material'noy Kul'tury AN SSSR 42: 135-140.

Vepraskas M.J., Lindbo D.L., Stolt M.H. 2018. Redoximorphic Features. In: G. Stoops, V. Marcelino, F. Mees (eds) Interpretation of micromorphological features of soils and regoliths. Elsevier: 425-445.

Vrydaghs L., Ball T., Devos Y. 2016. Beyond redundancy and multiplicity. Integrating phytolith analysis and micromorphology to the study of Brussels Dark Earth. Journal of Archaeological Science 68: 79-88. 